\title{
Functioning of the planktonic ecosystem on the Gulf of Lions shelf (NW Mediterranean) during spring and its impact on the carbon deposition: a field data and 3-D modelling combined approach
}

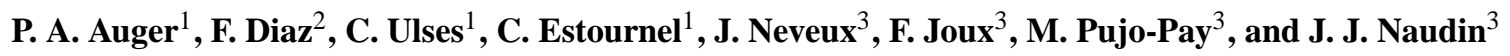 \\ ${ }^{1}$ Laboratoire d'Aérologie (LA), UMR5560, CNRS - Université de Toulouse, UPS, 14 avenue Edouard Belin, 31400 \\ Toulouse, France \\ ${ }^{2}$ Laboratoire d'Océanographie Physique et Biogéochimique (LOPB), CNRS - Aix-Marseille Université, Campus de Luminy, \\ 13288 Marseille, France \\ ${ }^{3}$ Laboratoire d'Océanographie MICrobienne (LOMIC), CNRS - Université Paris 6, Observatoire Océanologique, BP 44, \\ 66650 Banyuls/Mer, France
}

Received: 5 October 2010 - Published in Biogeosciences Discuss.: 14 December 2010

Revised: 30 September 2011 - Accepted: 12 October 2011 - Published: 11 November 2011

\begin{abstract}
A coupled hydrodynamic-biogeochemical modelling is developed to address main mechanisms that drive the particulate organic carbon (POC) deposition in the Gulf of Lions (NW-Mediterranean). Low-salinity water (LSW, salinity <37.5) lenses detached from the Rhone River plume under specific wind conditions tend to favour the biological productivity and provide a good opportunity for validating a planktonic ecosystem modelling. A specific calibration dedicated to river plume ecosystems is then proposed and validated using in situ measurements within such LSW lens (BIOPRHOFI cruise - May 2006) and on the Gulf of Lions. During spring 2006, the POC deposition is maximal on the prodelta area and within the coastal area in the Gulf of Lions. Organic detritus mostly contribute to the total POC deposition (82-92\%) whereas the contribution of living organisms (microphytoplankton) appears lower than $17 \%$. Exploring both influences of terrestrial inputs from the Rhone River and planktonic ecosystems on the POC deposition on the shelf, we estimated that the contribution of terrestrial POM inputs to the total POC deposition is lower than $17 \%$ at the shelf scale during the study period, with maxima during peak discharges of the Rhone River. The main deposition area of terrestrial POC is found in the vicinity of the river mouth in agreement with sediment data. On the other hand, a remarkable influence of marine biological processes on the POC deposition is highlighted further on the shelf (from 60 to $80 \mathrm{~m}$ depth). A tight feedback between zooplankton and POM contents in the water column is proposed to explain
\end{abstract}

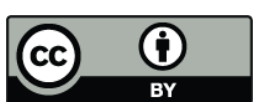

Correspondence to: P. A. Auger (pierre-amael.auger@aero.obs-mip.fr) the control of POC deposition by zooplankton: terrestrial POM inputs would favour the development of living organisms through photosynthesis and grazing processes increasing the retention of organic matter within the food web. By favouring the development of large-sized zooplankton, LSW lenses may have paradoxically a negative impact on the carbon deposition on the shelf. In the same way, peak discharges of the Rhone River finally increase the gradient of POC deposition between the prodelta and the offshore area in the Gulf of Lions. The biogenic elements from the Rhone River are then exported further offshore through advection of zooplankton communities on the Gulf of Lions shelf.

\section{Introduction}

River-dominated continental margins are characterized by large supplies of inorganic nutrients and organic materials that support high biological productivity (Lohrenz et al., 2008; Dagg et al., 2004). In such coastal zones, physical processes and plankton dynamics control the storage and transformation of terrestrial materials onto continental shelves towards the open sea (Green et al., 2006; Gao and Wang, 2008; Dagg et al., 2008). Besides high organic carbon deposition that occurs on the continental shelf, physical processes also induce an organic carbon export to the open sea. Each rivershelf-ocean system differs from the others, depending on the river inputs variability, anthropogenic impact, and dynamic and topographic physical environment. Moreover, the ongoing climate change may modify the atmospheric forcing and river runoffs, altering ecosystems and biological processes not necessarily in balance (Dagg et al., 2004). Conceptually,

Published by Copernicus Publications on behalf of the European Geosciences Union. 


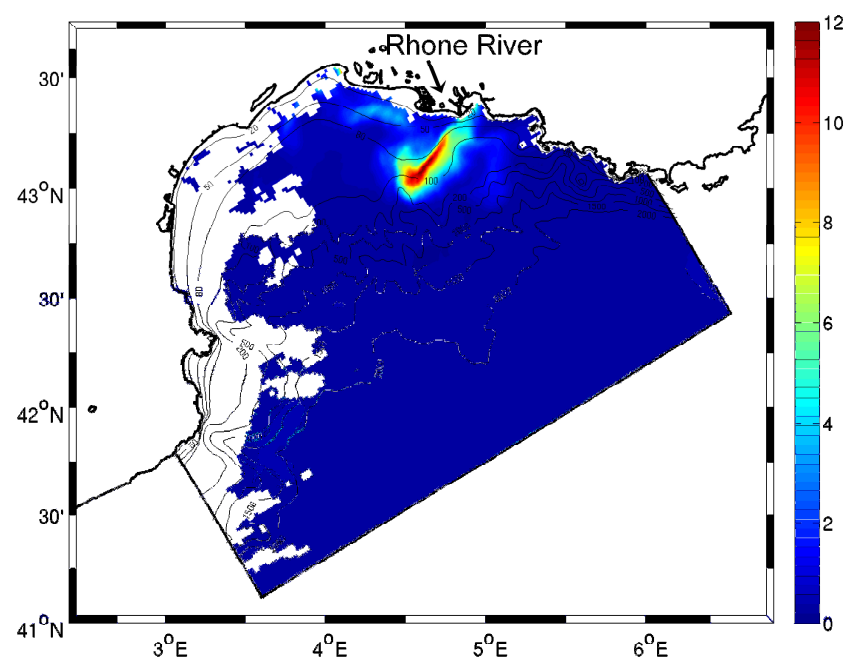

Fig. 1. Chlorophyll- $a$ concentration $\left(\mathrm{mgChl} \mathrm{m}^{-3}\right)$ from MODIS data on 19 May 2006.

the organic carbon buried in shelf sediments is made of living phytoplankton and organic detritus of both terrestrial and marine origin, such as dead planktonic cells and zooplankton fecal pellets. An evaluation of the different mechanisms that drive the fate of organic carbon within a continental shelf are then needed to account for potential changes in the carbon cycling at the river-sea connection.

The Rhone River is the major freshwater source of the Mediterranean Sea with runoffs $\sim 1750 \mathrm{~m}^{3} \mathrm{~s}^{-1}$ in average (Naudin et al., 1997), which currently makes the Gulf of Lions the most river-impacted coastal area of the Mediterranean Sea. Furthermore, extremes of precipitation and of river flow on the French Mediterranean area are likely to be modified in the future due to Climate Change (QuintanaSeguí et al., 2011). The current morphology of the Gulf of Lions results from sediment deposits since the last level rise $(\sim 20000 \mathrm{yr}$ ago). At this long time scale, Got and Aloisi (1990) estimated that $70 \%$ of particulate matter inputs are buried on the shelf whereas $30 \%$ are transported toward the slope and the open sea. Moreover, the fate of organic carbon in the Gulf of Lions has already been addressed by a compilation of sediment data representing different space and time scales (Durrieu de Madron et al., 2000). In this study, an alternative three-dimensional biogeochemical modelling is used to further investigate the dynamics of plankton ecosystem and transport of particulate organic matter on the Gulf of Lions shelf.

The Rhone River freshwater plume forms an extended dilution zone (Morel and André, 1991; Estournel et al., 2001), which has been defined as a region of freshwater influence (ROFI) by Simpson (1997). Accounting for the ROFI's characteristics, field surveys have been performed to understand the ecosystem functioning along the salinity gradient (Lefevre et al., 1997; Naudin et al., 1997, 2001; Pujo-Pay et al., 2006). Under specific wind conditions, low-salinity water (LSW) can, for instance, accumulate on the shelf to form confined structures (LSW lenses) propitious for high biological productivity, as shown by TChl- $a$ satellite images (Fig. 1), and for blooms of large-sized phytoplankton (Diaz et al., 2008). Precise biogeochemical measurements were performed in May 2006 within such LSW lenses and further on the Gulf of Lions (BIOPRHOFI - BIOlogical Processes in the RHOne Freshwater Influence, see Fig. 2). They provide an opportunity for validating an ecosystem model specifically dedicated to the Rhone ROFI system.

The objective of this paper is to improve our understanding of the mechanisms which control the deposition and export of particulate organic carbon (POC) in the Gulf of Lions. The first section of this paper presents the modelling tool used to carry out this study, with special attention being paid in the model calibration to the more and more severe phosphorus limitation (Ludwig et al., 2009) due to modifications of the Rhone River nutrients inputs impacting the plankton ecosystem productivity in the Gulf of Lions (Diaz et al., 2001). The second section details a robust validation of the ecosystem model actually performed using BIOPRHOFI data. The third section describes the organic carbon deposition during spring 2006 and the results of a sensitivity analysis to Rhone River inputs of particulate organic matter. Discussing the latter results, the fourth section focuses on the mechanisms driving the organic carbon deposition in the Gulf of Lions and the precise role of planktonic ecosystems.

\section{Material and methods}

\subsection{Model description}

\subsubsection{Three-dimensional hydrodynamic model}

The three-dimensional (3-D) primitive equations, sigmacoordinate, free surface SYMPHONIE hydrodynamic model used in this work was described in detail by Marsaleix et al. (2008). This model has been primarily used to describe the dynamics of the Rhone River plume and its response to wind forcing (Estournel et al., 1997, 2001; Marsaleix et al., 1998), and also succeeded in reproducing the coastal circulation in the Gulf of Lions (Estournel et al., 2003; Petrenko et al., 2008).

A strategy of embedded models is applied so as to represent small-scale hydrodynamic and biogeochemical processes within the Rhone River plume and the Gulf of Lions shelf: a $1.5-\mathrm{km}$ resolution model of the Gulf of Lions is forced at its boundaries by a 3-km resolution modelling of the North-Western Mediterranean region (Fig. 2a). The sigma coordinate system (40 levels) is refined near the surface to represent the sharp vertical salinity gradient associated to the plume. A Lax-Wendroff advection scheme for biogeochemical tracers (James, 1996) is also preferred to catch the strong 


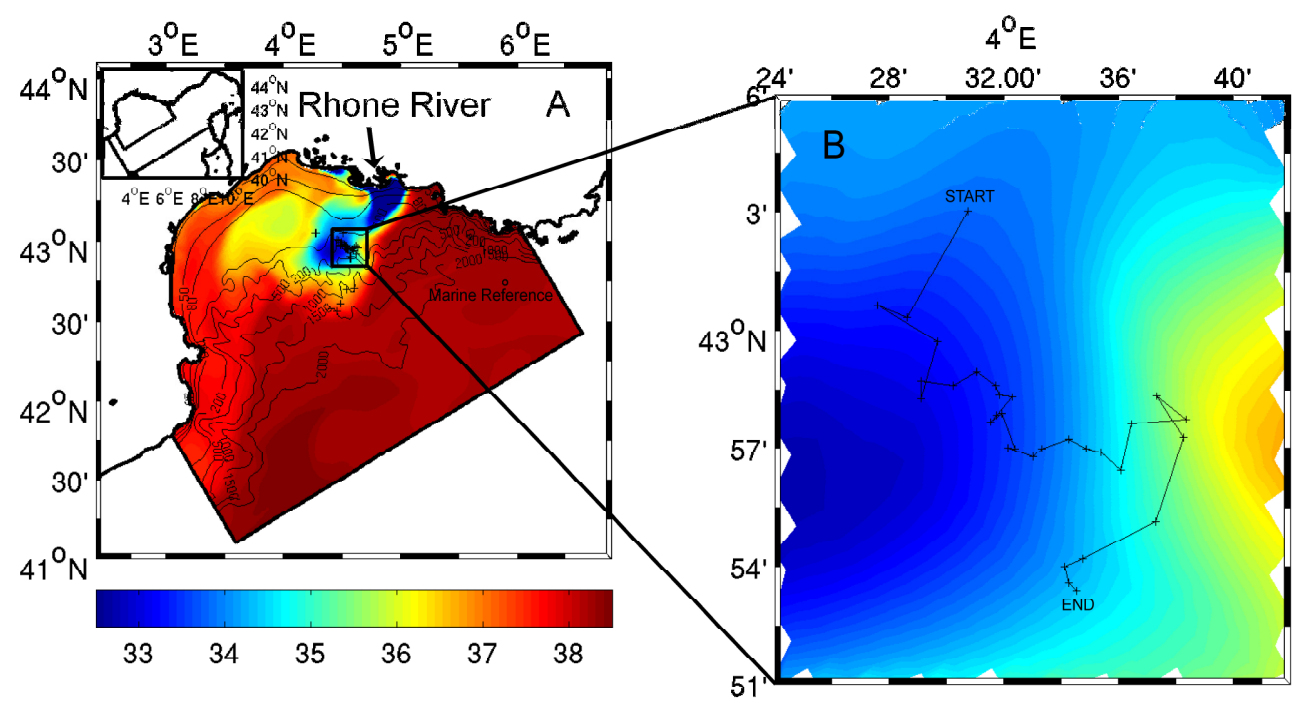

Fig. 2. Illustration of the embedded strategy (in the top left insert) and localization of the BIOPRHOFI stations (black dots) and the marine reference (black circle) on a salinity field simulated on 21 May 2006 (A). Zoom on the trajectory sampled in the LSW lens (B) from START to END station.

gradients between freshwater plume and surrounding marine water, as observed from space on the chlorophyll contents (e.g. see Fig. 1).

\subsubsection{Ecosystem model}

The ecosystem model used in this study is built to represent the ecosystem dynamics' complexity of the North-Western Mediterranean Sea and includes 34 state variables (Fig. 3). This model can be considered as a multi-nutrient and multiplankton functional types model (Le Quéré et al., 2005) since the biogeochemical cycle dynamics of several biogenic elements (carbon, nitrogen, phosphorus, and silica) and several pelagic plankton groups are simulated. Le Quéré et al. (2005) defined a set of key plankton functional types (PFT) that have to be included in ocean biogeochemistry models to capture important biogeochemical processes in the ocean. Thus, the structure of the model, and precisely the composition of PFT, has been chosen following a thorough analysis of the available experimental knowledge on the biogeochemical functioning of the NW Mediterranean Sea (e.g. Ferrier-Pagès and Rassoulzadegan, 1994; Christaki et al., 1996; Vidussi et al., 2000; Diaz et al., 2001; Avril, 2002; Marty et al., 2002; Moutin et al., 2002; Thingstad and Rassoulzadegan, 1995; Gaudy et al., 2003; Gomez and Gorsky, 2003; Leblanc et al., 2003; Pujo-Pay and Conan, 2003; Charles et al., 2005), as well as previous modelling studies (Tusseau et al., 1997; Babin et al., 2003; Levy et al., 1998; Lacroix and Grégoire, 2002; Raick et al., 2005, 2006). Resulting from this analysis, the model compartments are described below.

Three compartments of autotrophs from the smallest to the largest are accounted for: (1) pico-autotrophs, mainly Synechococcus (0.7-2 $\mu \mathrm{m}, \mathrm{Phy}_{1}$ in the model); (2) nanophy- toplankton $\left(2-20 \mu \mathrm{m}, \mathrm{Phy}_{2}\right.$ in the model) that dominate the biomass of phytoplankton assemblages for most of the year (Marty et al., 2002; Marty and Chiavérini, 2010) - this compartment is an assemblage of heterogeneous taxonomic composition (for example autotrophic dinoflagellates); and (3) microphytoplankton community $\left(20-200 \mu \mathrm{m}, \mathrm{Phy}_{3}\right.$ in the model) largely dominated by phytoplankton silicifiers (mainly diatoms) that can punctually contribute to a significant part of primary production and biomass during spring bloom in the NW Mediterranean Sea (Marty et al., 2002; Marty and Chiavérini, 2010). The main functional role of the latter group lies in their ability to contribute to matter export directly through direct shell and indirectly through fecal pellets sedimentation (via copepods grazing).

Four compartments of heterotrophs from the smallest to the largest ones are considered: (1) picoheterotrophs (mainly bacteria, $0.3-1 \mu \mathrm{m}$, Bac in the model) that implicitly remineralize dissolved organic matter and can compete, in some special circumstances, with small phytoplanktons for inorganic nutrients; (2) nanozooplankton (5-20 $\mu \mathrm{m}$, mainly bacterivorous flagellates and small ciliates, $\mathrm{Zoo}_{1}$ in the model) that consume the small phytoplankton group $(<2 \mu \mathrm{m})$ and bacteria; (3) microzooplankton (20-200 $\mu \mathrm{m}$, mainly most of ciliates groups and large flagellates, $\mathrm{ZoO}_{2}$ in the model) having characteristics (growth, ingestion rates...) close to the previous group but their preys spectrum being wider especially with potential consumption of microphytoplankton; and (4) mesozooplankton ( $>200 \mu \mathrm{m}$, mainly copepod groups but also including amphipods, $\mathrm{Zoo}_{3}$ in the model) grazing on the largest categories of plankton ( $>20 \mu \mathrm{m}$, microphytoplankton and microzooplankton) and producing fast-sinking fecal pellets. 


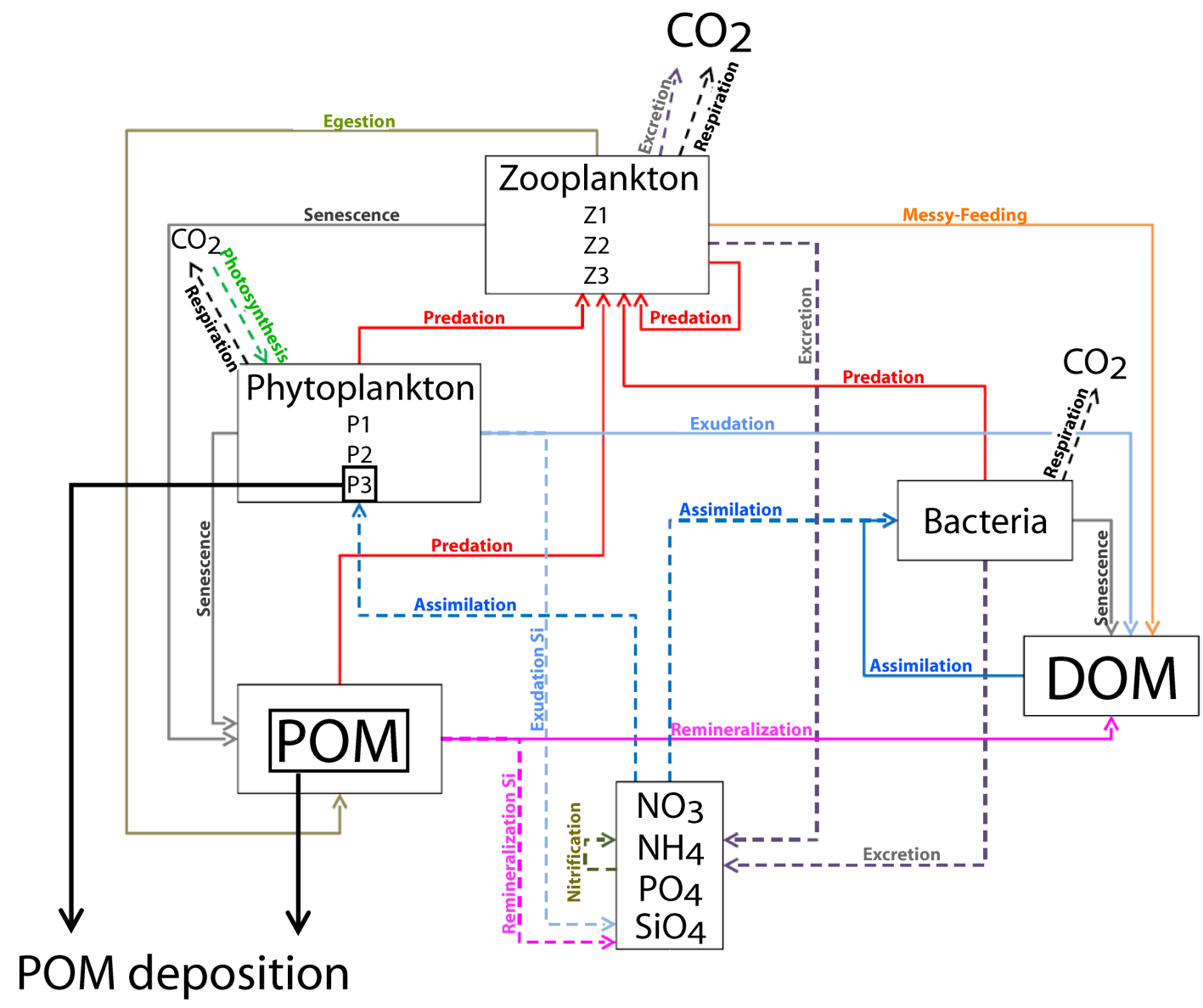

Fig. 3. Diagram of the ecosystem model indicating the biogeochemical interactions between the different compartments and the variables that participate to particulate organic matter deposition. Adapted from Herrmann (2010).

Four dissolved inorganic nutrients are considered. For nitrogen, nitrate and ammonium (Nut ${ }_{1}$ and $\mathrm{Nut}_{2}$ in the model) are distinguished, owing to their differential and high supplies by rivers as well as their distinct roles in the functioning of pelagic ecosystem (new vs. regenerated production). Dissolved inorganic phosphorus considered as phosphate (Nut3 in the model) plays an important role in the control of the primary productivity at some periods of the year (Diaz et al., 2001; Marty et al., 2002). Silicate (Nut 4 in the model) is also considered as it can punctually (e.g. at the end of bloom) limit the diatoms growth (Leblanc et al., 2003).

Dissolved organic matter (DOM, under the forms of $\mathrm{C}, \mathrm{N}$, and $\mathrm{P}$ ) is considered in the model as it is consumed by heterotrophic bacteria and for its importance in exported production (e.g. process of seasonal accumulation) in the NW Mediterranean Sea (Pujo-Pay and Conan, 2003). However, its potential consumption by the phytoplankton (Pujo-Pay et al., 2006) is not taken into account by the model. Particulate organic matter (POM, under the forms of C, N, P, Si, and chlorophyll) is divided in two size classes (small $<50 \mu \mathrm{m}$ and large $>50 \mu \mathrm{m}$, Det $\mathrm{S}_{\mathrm{S}}$ and $\operatorname{Det}_{\mathrm{L}}$, respectively, in the model), differentiated by their sinking velocity.
A realistic modelling of the Rhone River plume ecosystem has to account for the effects of terrestrial material inputs on marine ecosystem dynamics. Particulate inorganic matter (PIM) and coloured dissolved organic matter (CDOM) have been shown to contribute significantly to the absorption of light irradiance within the first upper metres of the ocean, all the more in such a river-influenced environment (Babin et al., 2003). A parameterization of the effect of PIM water content on the light absorption (Babin et al., 2003) was then added into the light module of the coupled model (Eq. B2). A contribution of CDOM absorption was furthermore introduced from in situ optical measurements (Para et al., 2010) in the Rhone River (Eq. B2).

List of abbreviations of the state variables and biogeochemical processes are given in Tables A1 and A2, respectively. Equations for the biogeochemical rates of change of the state variables and for the biogeochemical fluxes are presented in Tables A3 and A4, respectively. Model parameters are finally given in Tables A5 and A6. 


\subsubsection{Rhone River inputs}

Rhone River inputs of organic and inorganic material were daily monitored in Arles, about $50 \mathrm{~km}$ upstream the river mouth, from November 2005 to December 2006. This data set actually provides daily river runoffs as well as nitrate, phosphate, silicate, and particulate inorganic matter inputs (P. Raimbault, personal communication, 2009). Moreover, monthly observations of ammonium and dissolved organic carbon (DOC) inputs were performed by the French "Système d'Information sur l'eau du basin RhôneMéditerranée" (http://www.rdbrmc.com/cartordbrmc/).

Dissolved organic nitrogen (DON) and phosphorus (DOP) inputs were deduced considering average constant ratios, respectively, of DOC:DON $=19.4( \pm 14.1)$ and DOC:DOP $=325.3( \pm 195.9)$ calculated from daily measurements in the Rhone River in 2007-2008 (P. Raimbault, personal communication, 2009), knowing that these ratios are rather high during high river discharge. Particulate organic carbon (POC) inputs were estimated from an empirical linear relationship evidenced with Rhone River runoffs (Sempéré et al., 2000), and arbitrarily partitioned between small and large-sized particles considering a domination of dead microalgae (respectively, $90 \%$ and $10 \%$ of total). Particulate organic nitrogen (PON) and phosphorus (POP) inputs were then deduced considering average constant ratios POC:PON $=11.3( \pm 6.6)$ and POC:POP $=106.9( \pm 68.6)$ measured in the Rhone River in 2007-2008 (P. Raimbault, personal communication, 2009). Large-sized particulate organic silica (POSi) inputs were fixed equal to large particulate organic nitrogen inputs, considering that the pool of freshwater microalgae is dominated by diatoms. Particulate chlorophyll detritus inputs to the open sea, resulting from the osmotic lyses of freshwater phytoplankton species at the river mouth, were finally fixed at a constant value measured in the Rhone ( $3.7 \mathrm{mgChl} \mathrm{m}^{-3}$; Moutin et al., 1998).

\subsection{From in situ data to model calibration}

\subsubsection{Hydrodynamic framework during the BIOPRHOFI cruise}

A field study focused on LSW lenses located off the Rhone River mouth was carried out on board the French R/V Le Suroit during the BIOPRHOFI cruise (BIOlogical Processes in the RHOne Freshwater Influence - 14-28 May 2006). A lagrangian sampling strategy aimed at studying the evolution of the planktonic ecosystem inside LSW lenses detached from the Rhone River plume. A sub-surface Holey-sock buoy, drifting between 5 and $15 \mathrm{~m}$ depth, was thus tracked during $107 \mathrm{~h}$ (Fig. 2b) covering an area of about 70 square miles $\left(42^{\circ} 53^{\prime}-43^{\circ} 03^{\prime} \mathrm{N}\right.$ and $\left.4^{\circ} 28^{\prime}-4^{\circ} 39^{\prime} \mathrm{W}\right)$. Along this tracking, CTD profiles (SBE9/11+) were performed hourly and samples were collected using the CTD-rosette system every 2,6 , or $12 \mathrm{~h}$, depending on the parameters considered.
Additional stations were also sampled further on the Gulf of Lions shelf and slope (Fig. 2a).

During the BIOPRHOFI cruise, the daily Rhone River outflow ranged from 1239 to $2292 \mathrm{~m}^{3} \mathrm{~s}^{-1}$ with a 3-day peak discharge of over $2200 \mathrm{~m}^{3} \mathrm{~s}^{-1}$ from 20-22 May 2006. Low values of salinity firmly confirm the sampling of a LSW lens. According to all the salinity profiles operated hourly during the tracking, two layers have been distinguished in the sampled LSW: the surface layer, about $5 \mathrm{~m}$ thick with salinity lower than 36.6; and the underlying sub-surface layer, which can extend down to $35 \mathrm{~m}$ depth with salinity ranging from 36.6 to 38.25 . Deeper, marine water is characterised by a regular increase in salinity with depth up to 38.52 at $200 \mathrm{~m}$ depth.

\subsubsection{Biogeochemical analysis of BIOPRHOFI data}

All details on the sampling technique, hydrological data acquisition (salinity and temperature), and measurements of nutrients $\left(\mathrm{NO}_{3}, \mathrm{NH}_{4}, \mathrm{PO}_{4}\right.$, and $\mathrm{Si}$ ), dissolved organic carbon (DOC), total chlorophyll- $a$ (TChl- $a$, sensu Neveux and Lantoine, 1993), as well as bacterial abundance and activity are fully described in Joux et al. (2009). HPLC pigment analyses (chlorophylls, carotenoids) were also performed on some samples according to the method of Zapata et al. (2000). These analyses enabled assessment of the TChl- $a$ biomass of three size groups of phytoplankton (pico-, nano-, and microphytoplankton according to the average size of the cells) from the pigment grouping methodology proposed by Claustre (1994) and Vidussi et al. (2001), and recently improved by Uitz et al. (2006). These in situ phytoplankton biomasses can then be compared to the three aforementioned phytoplankton size classes (Phy $1, \mathrm{Phy}_{2}$, and $\mathrm{Phy}_{3}$ ) represented by the model. In the same way, an analysis of heterotrophic flagellates and ciliates activity and biomass observed during the cruise is presented by Christaki et al. (2009), and integrated biomass of copepods were measured by D. Bonnet (personal communication, 2009), allowing the comparison of zooplankton model outputs (resp. Zoo, $\mathrm{Zoo}_{2}$, and $\mathrm{Zoo}_{3}$ ) with in situ measurements.

As shown by Naudin et al. (2001), dilution plots representing salinity against nutrients, dissolved organic matter (DOM), and elemental ratios can provide relevant indications on the biogeochemical characteristics and functioning of such LSW lenses (Figs. 4 and 5). In such figures, a slope line represents the theoretical dilution of river materials in marine water calculated from measurements in the Rhone River (Salinity $=0$ ) and in marine water (black cross). A deviation from this slope line indicates the influence of biogeochemical processes.

All along the buoy tracking (Fig. 2b), the stations sampled in the surface layer $(0-5 \mathrm{~m})$ exhibit a large decrease in nitrate by a factor of 10 during the dilution of LSW lens in marine water (Fig. 4). Moreover, nitrate and silicate are consumed in a rather constant ratio, which suggests the development of 

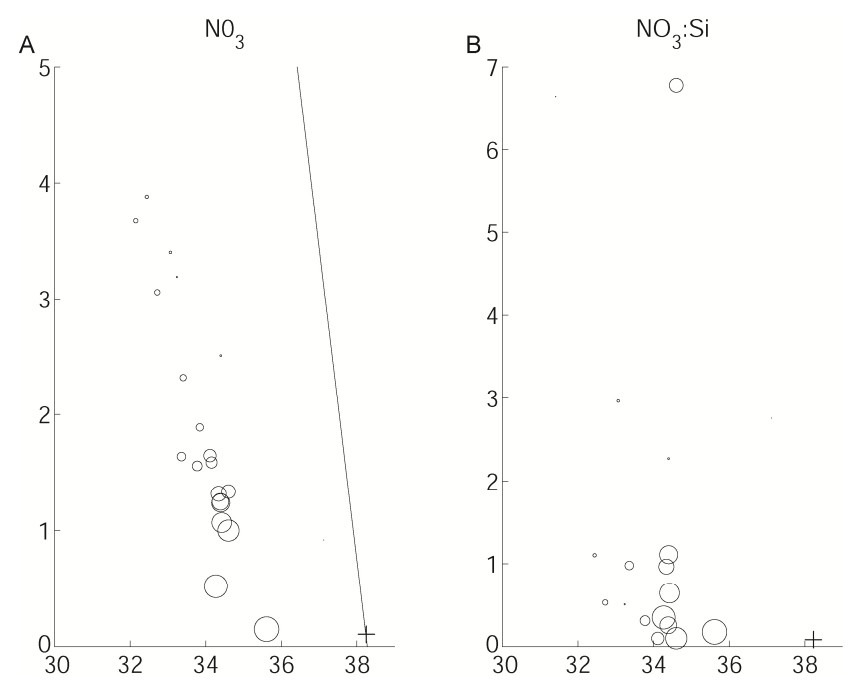

Fig. 4. Nitrate concentrations $\left(\mathbf{A}-\mathrm{mmolN} \mathrm{m}^{-3}\right)$ and nitrate:silicate ratio $\left(\mathbf{B}-\mathrm{mmolN} \mathrm{mmolSi}^{-1}\right)$ vs. salinity in the surface layer $(0-$ $5 \mathrm{~m}$ ) within LSW lens. Black cross indicates the marine reference. The size of the open circles increases along the trajectory (smallest open circle $=$ beginning of the trajectory, largest open circle $=$ end of the trajectory). The slope line is a theoretical dilution line accounting for a simple dilution of freshwater into marine water without any interaction of biological processes (see Naudin et al., 2001). A deviation from this slope line indicates the influence of biogeochemical processes. Values of nutrients under the detection limit are set to the detection limit.

siliceous phytoplankton in the LSW lens at the surface, as observed by Diaz et al. (2008) in a similar environment. On the contrary, a weaker subsurface (5-50 m depth) development of diatoms (not shown) could be due to a lower nutrients and light availability. While depleted at the beginning of the trajectory, phosphate contents at the surface increase by a factor of 6 (Fig. 5), which suggests an increasing trend of the recycling flux relative to that of uptake during the buoy tracking, already observed by Diaz et al. (2008). This seems to be corroborated by an opposite evolution of the DOC and phosphate contents (Fig. 5), which indicates a DOC uptake by heterotrophic bacteria actually enabled by phosphate availability in the surface layer. A decrease in bacterial production at the surface all along the trajectory (not shown) finally suggests a strong top-down control by ciliates and heterotrophic flagellates on bacteria and small size phytoplankton. Such control mainly exerted by mixotrophs, as shown by Christaki et al. (2009), may also explain why a decrease of $\mathrm{NO}_{3}: \mathrm{NH}_{4}$ is everywhere observed in the lens and whatever the measured salinity (not shown). Indeed, the top-down control on bacteria and small size phytoplankton may favour the development of large phytoplankton, explaining an important consumption of nitrate along the trajectory.
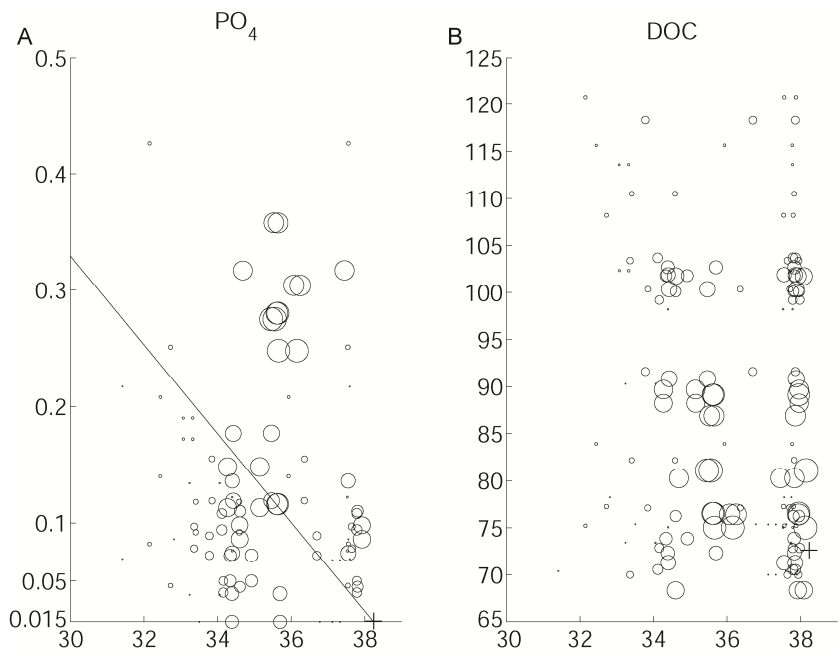

Fig. 5. Phosphate (A) and DOC (B) concentrations (resp. mmolP $\mathrm{m}^{-3}$ and $\left.\mathrm{mmolC} \mathrm{m}^{-3}\right)$ vs. Salinity in the surface layer $(0-$ $5 \mathrm{~m}$ ) within LSW lens. Black cross, size of open circles, and signification of the slope line are described in Fig. 4.

High surface concentrations of microphytoplankton defend the latter assumption (Fig. 6). This was confirmed by additional analyses providing the total chlorophyll- $a$ contents in the $<3 \mu \mathrm{m}$ and $>3 \mu \mathrm{m}$ fractions for some samples. In the $0-5 \mathrm{~m}$ freshwater layer, the $>3 \mu \mathrm{m}$ fraction represents $82-95 \%$ of the total. The total phytoplankton biomass is thus generally dominated by the microphytoplankton class, which represents 70 to $90 \%$ of the total (Fig. 6). Nanophytoplankton biomass is also higher than that of picophytoplankton, which however exhibits non-negligible values regarding the high nutrient environment of sampling. At the subsurface (not shown), the phytoplankton biomass is also generally dominated, but to a lower extent, by microphytoplankton and nanophytoplankton. Besides, a global decrease of the microphytoplankton biomass is observed during the dilution of LSW lens in marine water (Fig. 6). This somehow suggests an increasing competition between phytoplankton species for resources in an almost nutrient-depleted environment at the end of the trajectory (Fig. 4). On the whole, the total chlorophyll- $a$ contents are then found anti-correlated to salinity (Pearson's correlation coefficient of $-0.89, p<$ 0.01). Significant anti-correlation are also found between each phytoplankton size class and salinity (Table 1) and besides increasing with the plankton size, in agreement with the usual observation of more abundant large-sized phytoplankton in high nutrient and low salinity environment (Sarthou et al., 2005). On the other hand, the proportions of each phytoplankton size class to the total biomass are not correlated to salinity, suggesting that the structure of the plankton community is not constrained by dilution (e.g. Table 1).

The analysis of the BIOPRHOFI data set confirms some previous observations and a hypothesis proposed to explain 


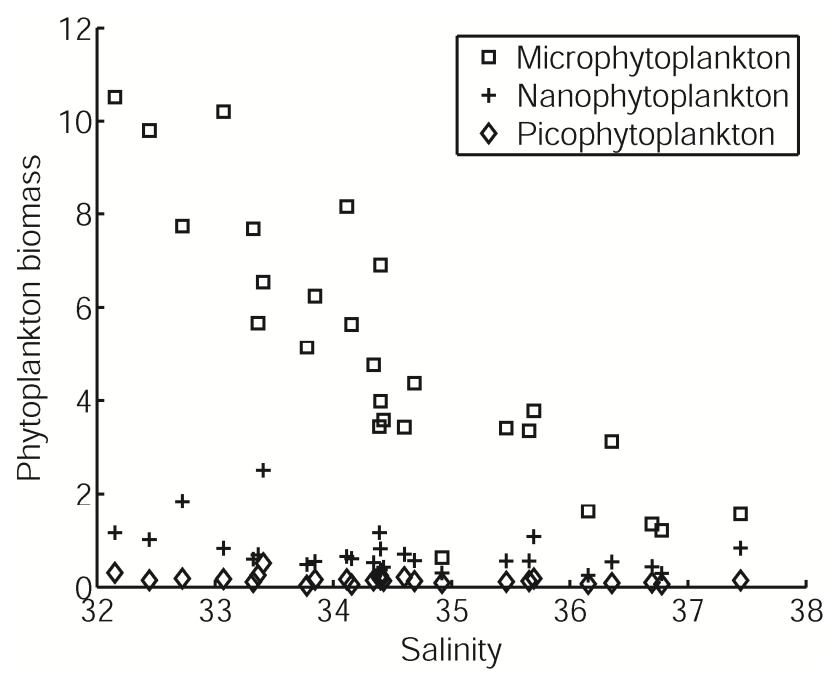

Fig. 6. Chlorophyll concentration in the surface layer $(0-5 \mathrm{~m})$ by phytoplankton size class $\left(\mathrm{mgChl} \mathrm{m}^{-3}\right)$ vs. salinity along the BIOPRHOFI trajectory in the LSW lens (see Fig. 2b).

the biogeochemical and ecological characteristics of LSW lenses (Diaz et al., 2008). Depending on wind conditions, these diluted water masses can detach from the river plume and evolve sometimes over hundreds of kilometres southwestward as shown by satellite images (Bosc, 2002). Considering that such LSW lenses have also been observed in other ROFIs through field data or remote sensing observations (Schumacher et al., 1993; Gilbes et al., 2002; Ressler and Jochens, 2003), the present data set is an opportunity for building and validating beyond the Gulf of Lions a biogeochemical modelling of the planktonic ecosystem dynamics for such marine environment.

\subsubsection{Calibration of the ecosystem model}

Several recent biogeochemical modelling works of the Mediterranean Sea and Black Sea ecosystems exhibit significant phytoplankton biomass underestimations in coastal nutrient-rich zones, while the phytoplankton fields simulated offshore in both basins are in better agreement with remote sensing observations: see, for example, the Pô River dilution zone in the Adriatic Sea (Polimene et al., 2006) and that of the Danube River in the Black Sea (Grégoire et al., 2004). The main reason for such performances invoked in these studies is the use of parameters rather unadapted to such nutrient-rich environments. To avoid this bias, a set of parameters specially dedicated to the Rhone River plume environment has been designed considering the plume-specific diversity of plankton communities (e.g. bold parameters in Table A5) as well as the high but unbalanced nutrient inputs from the river (Moutin et al., 1998; Bianchi et al., 1999; Joux et al., 2005; Ludwig et al., 2009).
A first characteristic concerns the macro-nutrient availability in river freshwater and the corresponding $\mathrm{N}: \mathrm{P}$ ratios in marine phytoplankton. Nutrient measurements in the Rhone River from November 2005 to December 2006 (P. Raimbault, personal communication, 2009) reported DIN:DIP ratios always higher than 34.8 (86.9 in average), suggesting a strong phosphate control of the biological activity near the river mouth. In such P-limited conditions, very fast $\mathrm{P}$ turnover rates or regeneration rates might allow phytoplankton to take up and store additional $\mathrm{N}$ in excess of the Redfield ratio without increasing the algal biomass (Yin et al., 2004). In this context, the maximal $\mathrm{N}: \mathrm{C}$ and $\mathrm{P}: \mathrm{C}$ quotas were chosen high and low, respectively, for all phytoplankton size classes. Earlier phosphate consumption by bacteria rather than phytoplankton was observed close to the river mouth (Cotner and Wetzel, 1992; Pujo-Pay et al., 2006), bacterioplankton also taking advantage of a large supply in DOC. As a consequence, the maximal P:C quota was chosen higher for bacteria than for phytoplankton.

Although experimental estimations of half-saturation constant for phosphate-uptake by phytoplankton remain scarce, Timmermans et al. (2005) reported values between 0.014 and $0.094 \mathrm{mmol} \mathrm{m}^{-3}$ for picophytoplankton. Furthermore, Tyrrell and Taylor (1996) used values of 0.05 and $0.1 \mathrm{mmol} \mathrm{m}^{-3}$ (resp. for Emiliania huxleyi and diatoms) in a modelling study of the NE Atlantic. To represent a drastic P-limitation of phytoplankton assemblage, half-saturation constants for phosphate uptake were fixed one order of magnitude above those of the aforementioned literature, while that of bacteria was set at an average value (Thingstad, 2005). Moreover, the model of Geider et al. (1998) used in the photoacclimation module of our model shows Chl:N internal ratios increasing with decreasing growth rates. Thus, the Chl:N maximal quotas were chosen increasing from pico- to nanoand microphytoplankton, which remain the most phosphorus limited.

Finally, microzooplankton and mesozooplankton grazing rates were adapted to fit observed zooplankton biomass. Microzooplankton maximum grazing rate was set to a relatively high value in agreement with high ingestion rates observed in the Rhone River plume (Christaki et al., 2009). On the contrary, the maximum grazing rate of mesozooplankton was fixed to a very low value according to in situ measurements from Gaudy et al. (1990).

\section{Validation of the ecosystem modelling}

A statistical analysis was carried out to evaluate the performances of the model to represent temperature, salinity and biogeochemical observations. The correlation coefficient was traditionally calculated ( $R=0$ non relationship, $R=1$ perfect fit; Fig. 7a), with the significant threshold for each variable (white diamonds). The bias was also calculated (Fig. 7b) as well as the ratio of standard deviation of the data 
Table 1. Statistical analysis of the relationship between salinity and total chlorophyll- $a$ concentration, chlorophyll- $a$ concentration in each phytoplankton size class, and contribution of each size class to total chlorophyll- $a$ concentration: the significance of the Pearson's correlation coefficients $(R)$ are calculated from the Pearson table and the number of samples (Sokal and Rohlf, 1995).

\begin{tabular}{lcc}
\hline Chlorophyll- $a$ vs. Salinity & Correlation coefficient $(R)$ & Significance \\
\hline TChl- $a$ & -0.89 & $99 \%$ \\
\hline Chlorophyll by phytoplankton size class & & \\
\hline Microphytoplankton & -0.80 & $99 \%$ \\
Nanophytoplankton & -0.64 & $99 \%$ \\
Picophytoplankton & -0.41 & $85 \%$ \\
\hline Contribution of each size class & & \\
\hline Microphytoplankton & 0.04 & null \\
Nanophytoplankton & -0.09 & null \\
Picophytoplankton & 0.20 & null \\
\hline
\end{tabular}

to model (RSD, Fig. 7c), which illustrates the differential dispersion between model outputs and data. As previously used in some modelling studies (e.g. Allen et al., 2007), the cost function score was also computed (CF, Fig. 7d) to assess the model data misfits compared with the standard deviation of the data: $\mathrm{CF}<1=$ very good, $1-2=$ good, $2-3=$ reasonable, $>3$ = poor; see Radach and Moll (2006).

\subsection{Validation of the hydrodynamic model}

According to salinity measurements, the vertical structure of the sampled LSW lens is composed of three distinct layers, which are accurately represented by the hydrodynamic model (not shown). Moreover, comparison of salinity model outputs against data shows a correct representation of the salinity gradient and freshwater plume extension (Fig. 8a). The statistical scores indicate a significant correlation coefficient, low percent bias, and very good RSD and cost function scores (Fig. 7). The large number of samples (238) gives even more significance to these statistics. Regarding temperature (Fig. 8 b), scores are globally very good despite an underestimation of simulated temperatures $\left(\sim 0.4^{\circ} \mathrm{C}\right)$. However, the density distribution inside the river plume being mostly driven by salinity (Marsaleix et al., 1998), this bias has very little influence on this buoyant structure hydrodynamics'. Moreover, such a temperature underestimation corresponds to a $2.8 \%$ underestimation of the $Q_{10}$ temperature function (see Eq. A57) and has then little effect on biogeochemical processes. In conclusion, both spatial extension and temporal evolution of the freshwater dilution area are accurately represented by the hydrodynamic model, both in terms of salinity and of temperature. This is actually an important asset for a robust modelling of the ecosystem dynamics in the area.

\subsection{Validation of the ecosystem model}

Considering the spatial errors inherent to the coupled hydrodynamic-ecosystem model, an accurate point-by-point spatial comparison between ecosystem model outputs and field observations appeared definitely unsuitable. Since freshwater distribution has been demonstrated to mostly control the biogeochemical processes within the plume (Naudin et al., 2001), an additional salinity criterion was considered to produce the ecosystem model validations. Inside of $20 \mathrm{~km}$ square boxes centred on each BIOPRHOFI station, only model cells which answered to the criterion " $\mid$ Salinity model $_{\text {- Salinity }}$ observation $\mid<0.25$ " were selected. The corresponding biogeochemical values were then averaged and compared to measured data through both a visual analysis (stocks in Fig. 9 and fluxes in Fig. 10) and an approach based on statistical scores (Fig. 7; e.g. Allen et al., 2007). By the way, a sensitivity test was conducted to assess the little influence of box size on the model/data comparison (not shown).

\subsubsection{Stocks outputs}

Model outputs of $\mathrm{NO}_{3}$ and $\mathrm{PO}_{4}$ concentrations fit quite correctly to in situ measurements (Fig. 9), which is confirmed by significant correlation coefficients (Fig. 7a). The model shows lower performances for reproducing $\mathrm{NH}_{4}$ concentrations. Hence, cost function (Fig. 7d) and RSD scores (Fig. 7c) are good to very good except for ammonium. Despite an overestimation of DIN $\left(\mathrm{NO}_{3}+\mathrm{NH}_{4}\right)$ concentrations on several stations (bias $>+40 \%$; Fig. $7 \mathrm{~b}$ ), such statistical scores then ensure a reasonable representation of the balance between both processes of uptake and regeneration of nitrogen and phosphorus. 

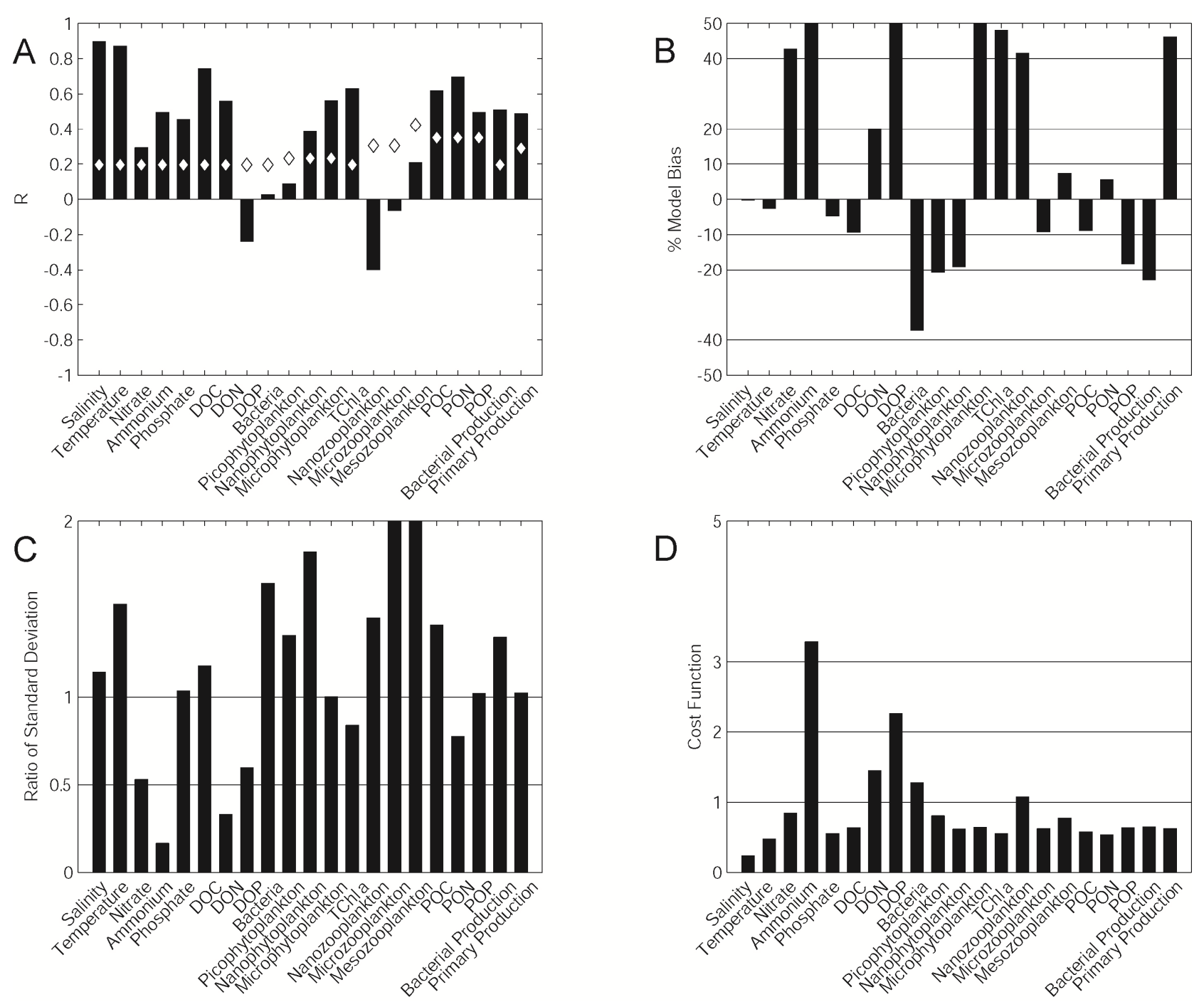

Fig. 7. Model performance statistics: correlation coefficient (A), model bias (B), cost function (C), ratio of standard deviation (D). White diamonds indicate the correlation significance at $95 \%$, depending on the number of samples.

As attested by a significant correlation coefficient and very good cost function and RSD scores (Fig. 7), DOC concentrations appear correctly represented by the model. DON outputs show a significant correlation coefficient, a good cost function score, but a poor RSD score; on the contrary, DOP concentrations are on the whole weakly represented (Fig. 9), as shown by a negative correlation coefficient and very poor cost function score (Fig. 7). Whereas DOC concentrations are underestimated (bias $\sim-10 \%$ ), both DON and DOP concentrations are overestimated (resp. bias $\sim+20 \%$ and $+50 \%$ ) maybe due to inaccurate Rhone River loads in the model. Otherwise, the balance between phytoplankton exudation and bacterial consumption of dissolved organic matter could be rather correctly represented regarding carbon, but poorly regarding nitrogen and phosphorus. The effective coupling of exudation and uptake processes in the model could lead to overestimate both nitrogen and phosphorus exudation by phytoplankton (see Eq. A26) since phytoplankton groups growing at the maximal N:C and P:C quotas (not shown) appear to be nitrogen- and phosphorus-replete in the LSW lens. Finally, Naudin et al. (2001) pointed out a potential alteration of microbial assemblages along the salinity gradient, actually confirmed by the analysis of BIOPRHOFI data (Joux et al., 2009). Very poor statistical scores for bacterial biomass (no correlation and bias $\sim-40 \%$ ) could reflect a too simplistic representation of bacterial communities in the model. A modification in the balance for biogenic elements needs by bacteria could therefore explain such overestimations of DON and DOP concentrations.

The three phytoplankton functional groups and the total chlorophyll- $a$ (TChl- $a$ ) contents are visually well predicted by the model (Fig. 9), resulting in reasonable to 

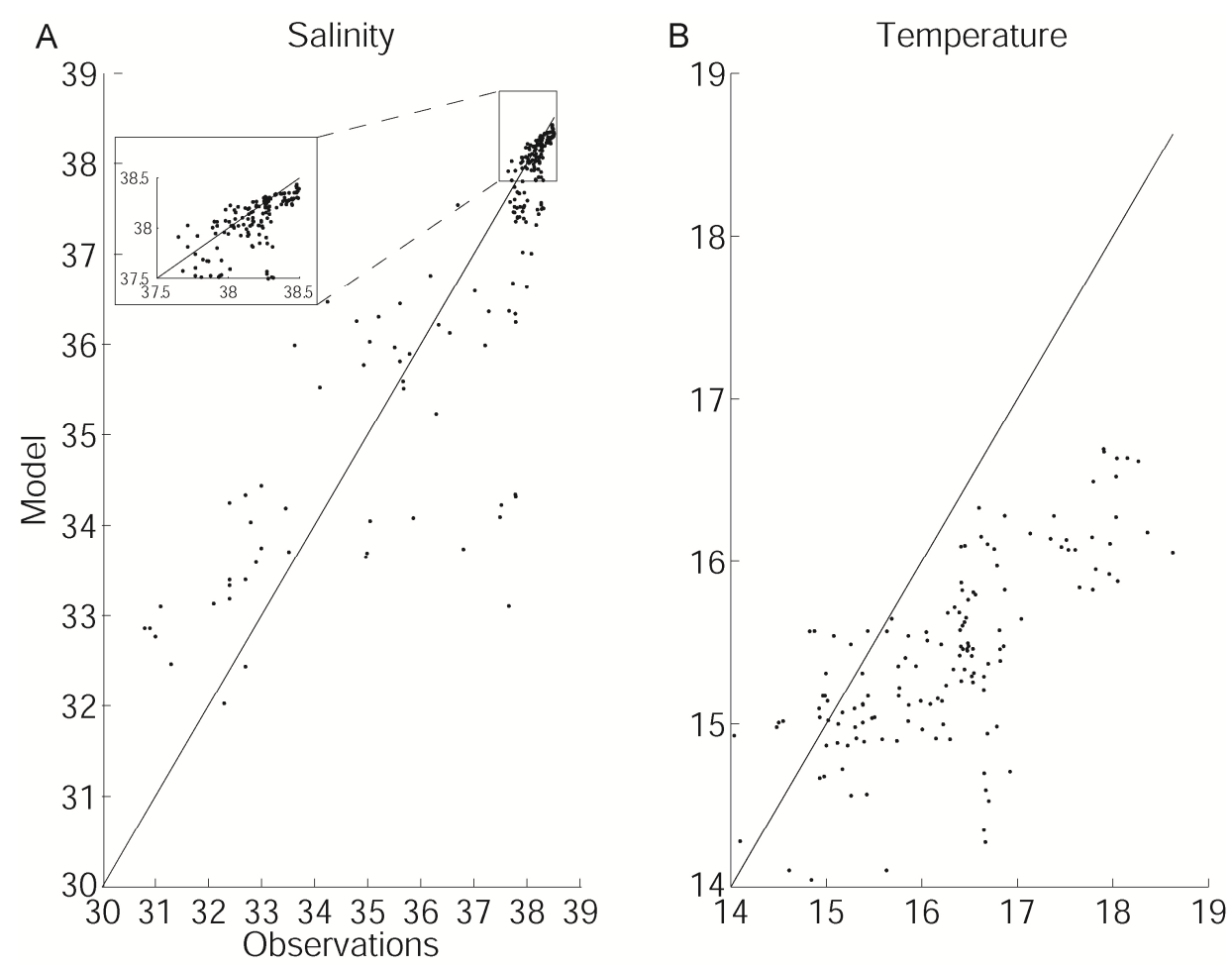

Fig. 8. Comparison between observations and model outputs for salinity $(\mathbf{A})$ and temperature $\left(\mathbf{B}-{ }^{\circ} \mathrm{C}\right)$.

good statistical scores (Fig. 7). However, pico- and nanophytoplankton exhibit some underestimated values (bias $\sim-20 \%$ ), whereas microphytoplankton and finally total chlorophyll biomass can be largely overestimated on some samples (bias $>+40 \%$ ).

Despite excellent RSD and reasonable cost function scores, the model does not catch the variability of the nanozooplankton biomass (Fig. 9), as model outputs are found anti-correlated with data and exhibit marked overestimations (Fig. 7, bias $>+40 \%$ ) at low concentrations $\left(\sim 1 \mathrm{mmolC} \mathrm{m}^{-3}\right)$ and underestimations at high concentrations. Microzooplankton is parameterized to partly feed on nanozooplankton and may contribute to the nanozooplankton overestimation in the LSW lens, but diverse sensibility tests on the microzooplankton feeding preferences did not improve the results. In spite of a very good cost function score, the simulated microzooplankton biomass is found weakly correlated maybe due to a misrepresentation of predation processes. Nevertheless, the order of magnitude is in agreement with the measured data range (bias $<-10 \%$ ). Besides, the mesozooplankton biomass is also found insignificantly correlated to data despite very good cost function scores and low bias on both trajectories (bias $<+10 \%$ ). Both processes of vertical migration and aggregation are not considered in the model and could explain such discrepancy. Extreme values are not well simulated, mesozooplankton biomass appearing limited to a threshold of $\sim 0.3 \mathrm{mmolC} \mathrm{m}^{-3}$. The use of a closure term to simulate mesozooplankton consumption by higher trophic levels (see Eq. A44) could additionally induce a too strong control of mesozooplankton biomass within the LSW lens, as already attested by Mitra (2009).

Finally, as shown by a good visual fit to data, the observed variability of the particulate organic carbon, nitrogen, and phosphorus contents are accurately simulated by the model (Fig. 9). Significant correlation coefficients are found with good RSD and cost function scores as well as low bias (Fig. 7, $\mid$ bias $\mid<20 \%$ ), although the latter statistical results have to be cautiously regarded owing to the low number of data. Moreover, the vertical gradient of POC concentrations is clearly represented by the model considering all available stations with POC data (Fig. 11). The POM contents are highly dependent on the whole food web activity as well as sedimentation and recycling processes in the water column (Tesi et al., 2007; Aller, 1998). As a consequence, a realistic representation of their vertical distribution is probably the most complicated to achieve. No data is available during the BIOPRHOFI cruise to validate the vertical fluxes of POM produced by the model. Nevertheless, we assume that the representation of the vertical gradient of POM concentrations will provide us an accurate estimation of these fluxes. 

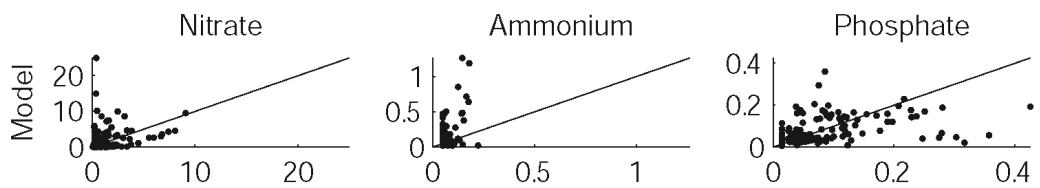

Observations

Picophytoplankton

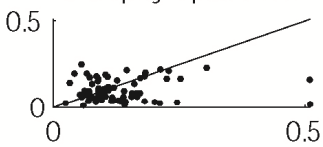

Nanophytoplankton

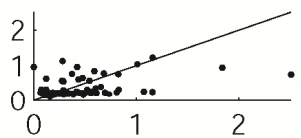

Microphytoplankton
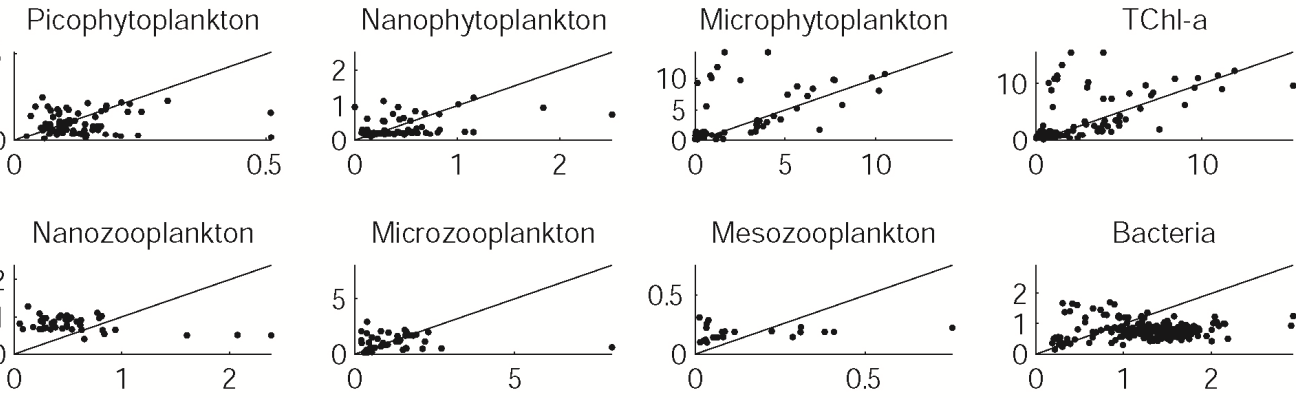

Microzooplankton
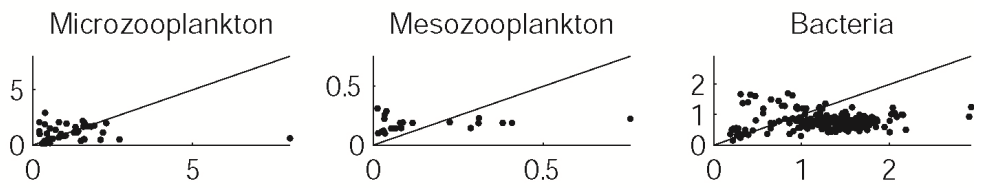

DOC
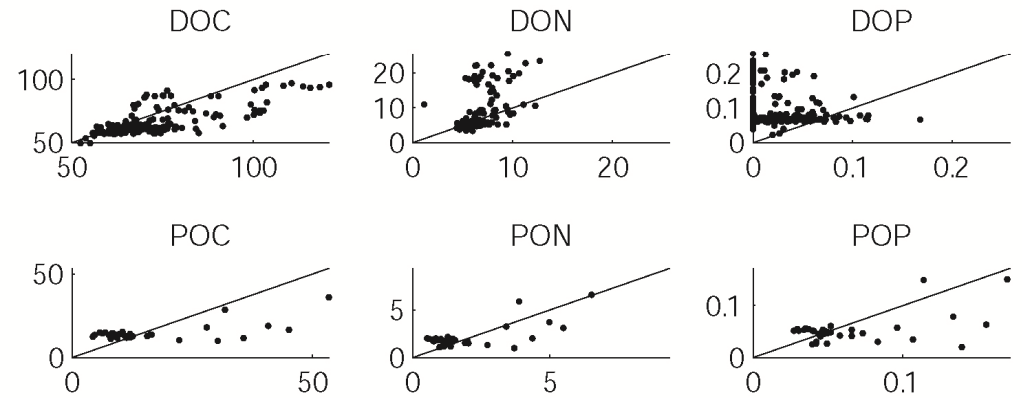

Fig. 9. Comparison between observations (x-axis) and model outputs (y-axis) of biogeochemical stocks measured during the BIOPRHOFI cruise. Units are $\mathrm{mmol} \mathrm{m}^{-3}$ for nutrients (expressed in $\mathrm{N}, \mathrm{P}$ ), $\mathrm{mgChl} \mathrm{m}^{-3}$ for phytoplankton, $\mathrm{mmolC} \mathrm{m}^{-3}$ for zooplankton and bacteria, and $\mathrm{mmol} \mathrm{m}{ }^{-3}$ for dissolved and particulate organic matter (expressed in $\mathrm{C}, \mathrm{N}, \mathrm{P}$ ).

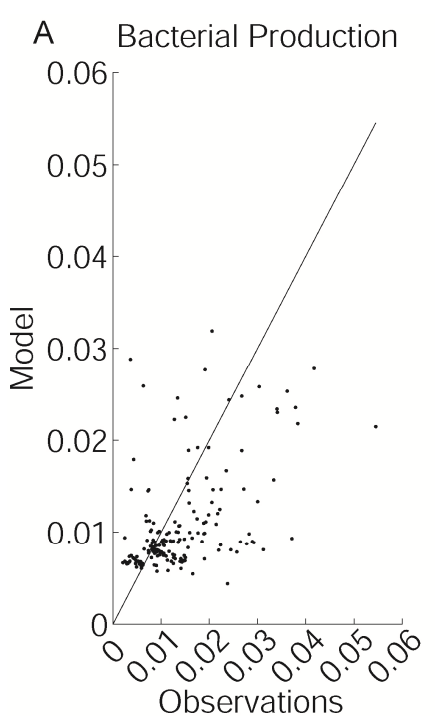

Fig. 10. Comparison between observations (x-axis) and model outputs (y-axis) of bacterial production $\left(\mathbf{A}-\mathrm{mgC} \mathrm{m}^{-3} \mathrm{~d}^{-1}\right)$ and primary production $\left(\mathbf{B}-\mathrm{mgC} \mathrm{m}^{-3} \mathrm{~d}^{-1}\right)$ measured during the BIOPRHOFI cruise.

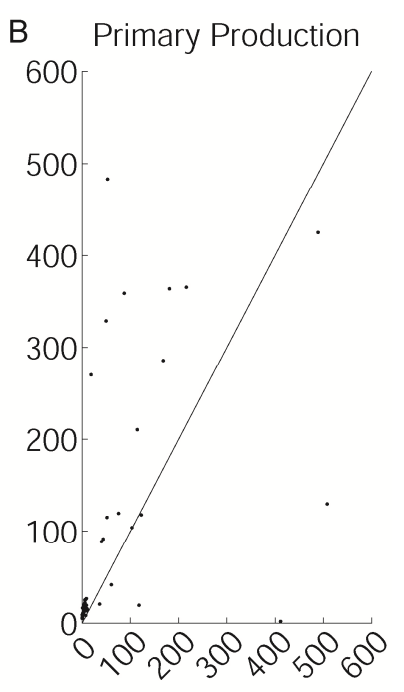

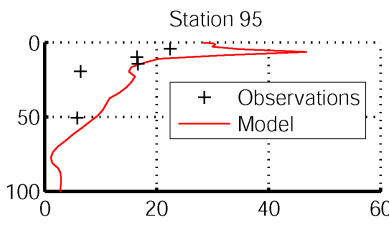
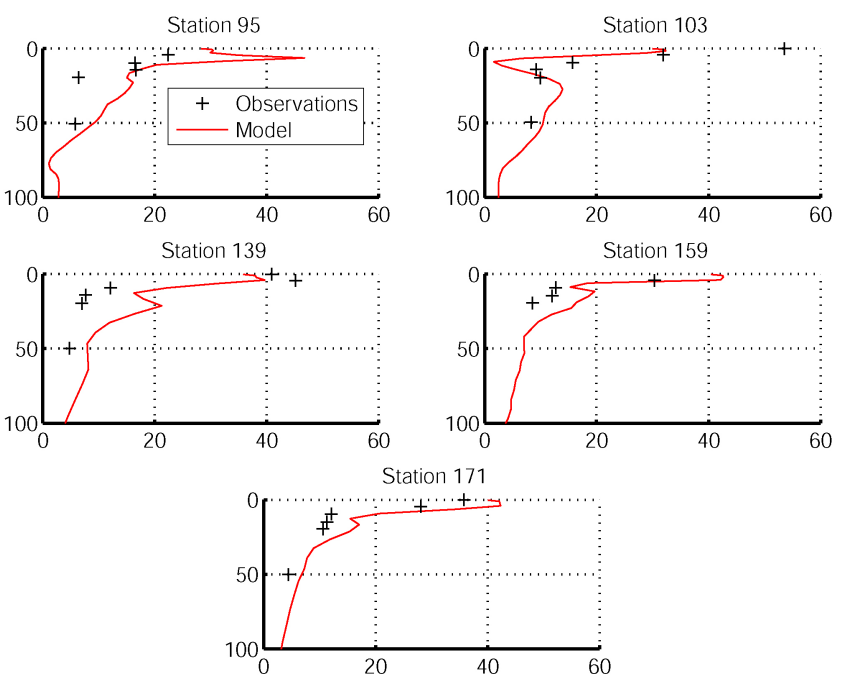

Fig. 11. Comparison between observed and simulated vertical profiles of particulate organic carbon concentrations $\left(\mathrm{mmolC} \mathrm{m}^{-3}\right)$ in the LSW lens. 

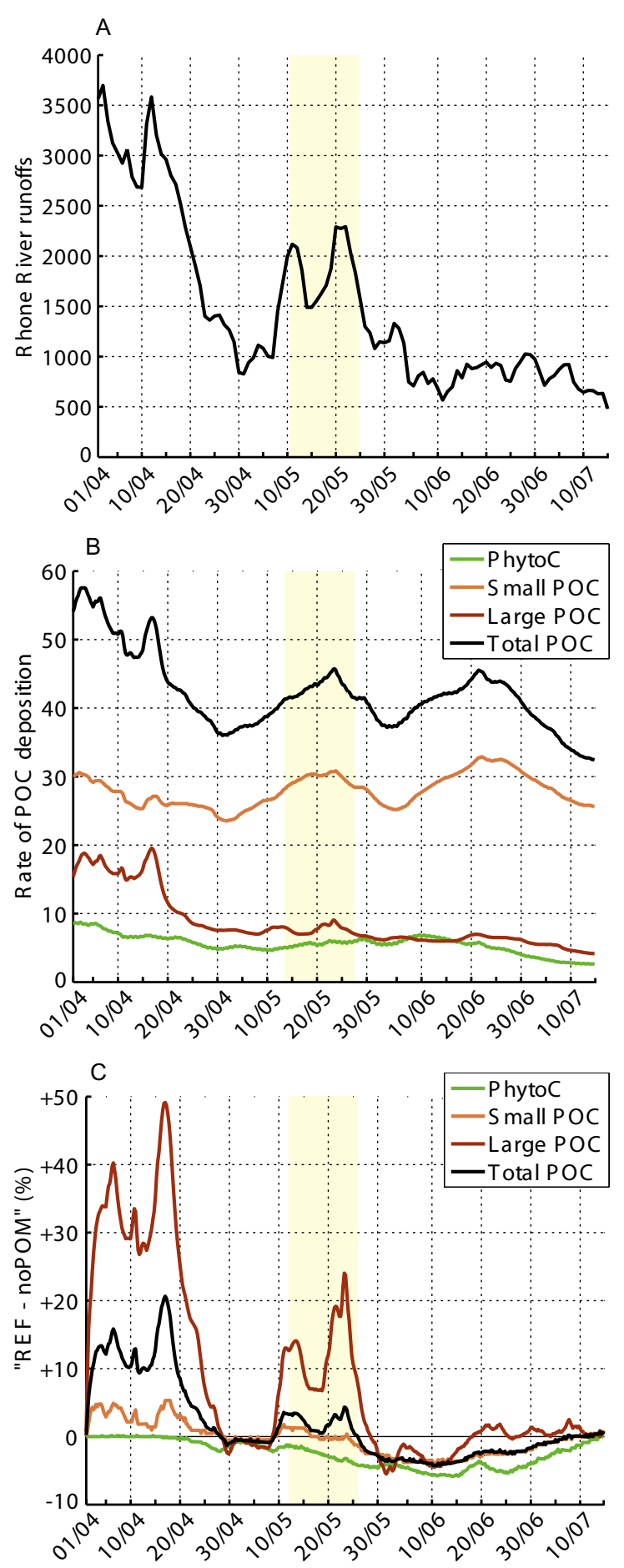

Fig. 12. Rhone River runoffs $\left(\mathbf{A}-\mathrm{m}^{3} \mathrm{~s}^{-1}\right)$, daily particulate organic carbon deposition rate averaged on the Gulf of lions shelf $(\mathbf{B}-$ $\mathrm{mgC} \mathrm{m}^{-2} \mathrm{~d}^{-1}$ ), and normalized difference between daily particulate organic carbon deposition rates from reference and "noPOM" simulations $(\mathbf{C}-$ in \%) from 1 April to 15 July 2006. Yellow stripe $=$ BIOPRHOFI period.

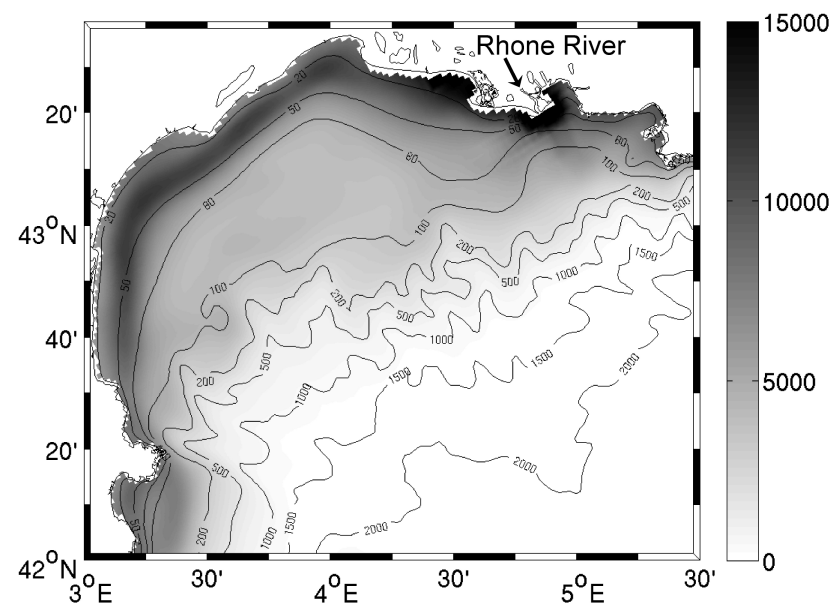

Fig. 13. Map of the particulate organic carbon deposition simulated by the model and cumulated from 1 April to 15 July 2006 $\left(\mathrm{mgC} \mathrm{m}^{-2}\right)$.

\subsubsection{Flux outputs}

The prediction of the transfer of carbon toward sediments and/or higher trophic levels requires a realistic assessment of carbon consumption (bacterial production) and gross primary production (photosynthesis) by the model. First, the bacterial growth is only supported by the bacterial production (fraction of the DOC uptake, see Eq. A6) in the biogeochemical model. While bacterial biomass is poorly represented (see above), simulated fluxes show a reasonable agreement with those observed (Fig. 10a) as confirmed by a significant correlation coefficient and very good cost function and RSD scores (Fig. 7); the computation of bias however shows a slight underestimation (bias $\sim-20 \%$ ). Second, simulated gross primary production rates by marine phytoplankton visually fit to data (Fig. 10b) as confirmed by a significant correlation coefficient, very good RSD (close to 1 ) and cost function score (Fig. 7). The overall trend is however an overestimation of carbon fixation with a mean bias of $\sim+45 \%$.

\section{Results}

The key factors which control the particulate organic carbon (POC) deposition on the Gulf of Lions shelf are now evaluated (Fig. 12), precisely the role of terrestrial POM inputs and biological processes. From 1 April to 15 July 2006, the daily Rhone River flow ranged from 480 to $3700 \mathrm{~m}^{3} \mathrm{~s}^{-1}$ (Fig. 12a), with two peak discharges over $2500 \mathrm{~m}^{3} \mathrm{~s}^{-}$(from 1 to 15 April) and $1500 \mathrm{~m}^{3} \mathrm{~s}^{-1}$ (from 8 to 25 May). Precisely, a 3-day peak discharge of over $2200 \mathrm{~m}^{3} \mathrm{~s}^{-1}$ occurred during the BIOPRHOFI cruise. Since the model was calibrated on BIOPRHOFI data, this spring period appeared appropriate to carry out our study. 


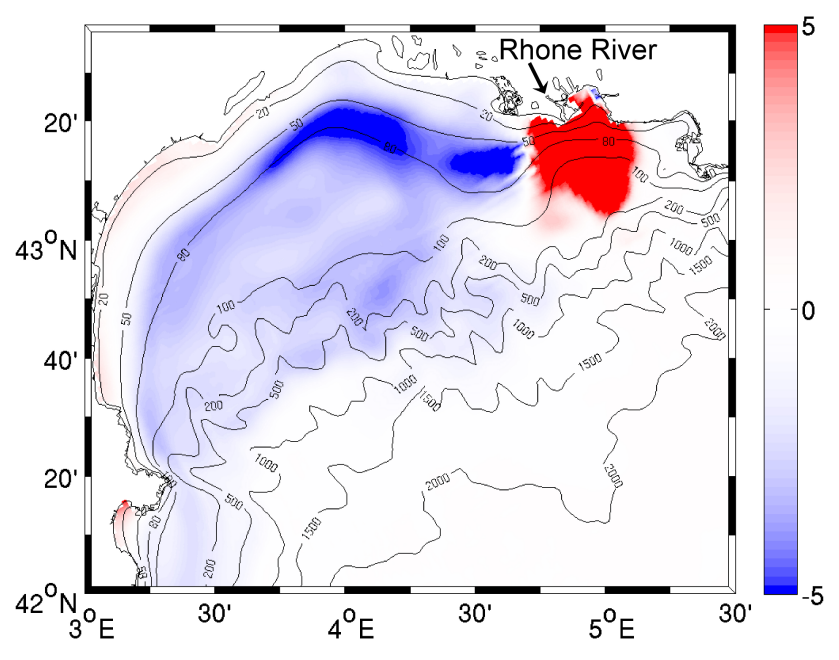

Fig. 14. Map of the normalized difference cumulated from 1 April to 15 July 2006 between the particulate organic carbon deposition from reference and "noPOM" simulations (in \%).

\subsection{POC deposition on the Gulf of Lions}

It is assumed that the POC deposition rate is a function of the particulate organic carbon concentration near the bottom and its settling velocity. The pool of particulate organic carbon involved in this process is composed of microphytoplankton (hereafter PhytoC) as well as small and large organic detritus (Dets and Det $_{\mathrm{L}}$ in the model, hereafter SPOC and LPOC) of terrestrial or marine origin (see Eqs. A7 and A10).

The map of the POC deposition cumulated during the study period (Fig. 13) shows that the transfer to the sediment is mainly located near the coast from the Rhone River mouth to the south-western exit of the Gulf of Lions. The mean cyclonic circulation actually induces the concentration of plume-originated material and its transport along the coast until reaching the deep sea. Spatially (not shown), the LPOC contribution is very limited to the river mouth vicinity. On the contrary, both SPOC and phytoplankton contributions mostly concern the entire shelf. As total POC (Fig. 13), both phytoplankton and SPOC contributions are found maximum between 20 and 50-70 m depth, in agreement with high accumulation rates and high organic carbon contents observed in shelf sediments from 30 to $50 \mathrm{~m}$ depth (Durrieu de Madron et al., 2000). The model results also corroborate the alongshore predominant dispersion of the terrestrial material from the Rhone River, described from long-term data by Got and Aloisi (1990).

Durrieu de Madron et al. (2000) assessed the contributions of river supply, atmospheric depositions, and primary production and estimated the total deposition of particulate organic carbon on the Gulf of Lions shelf (depth $<200 \mathrm{~m}$ ) in the range $20-67 \mathrm{mgC} \mathrm{m}^{-2} \mathrm{~d}^{-1}$. This range is assessed at a secular scale and cannot represent seasonality and extreme events such as peak discharges acting at a daily scale. Nev- ertheless, they are very close to our simulated values of organic carbon deposition rates averaged over the Gulf of $\mathrm{Li}^{-}$ ons shelf lying in the range $36-58 \mathrm{mgC} \mathrm{m}^{-2} \mathrm{~d}^{-1}$ from 1 to 15 July 2006 (Fig. 12b).

During the study period, the daily total POC deposition on the shelf is dominated by the SPOC contribution (50-80\%), and then most of the time by the LPOC contribution (12$37 \%$ ). The phytoplankton contribution is globally weaker (8-17\%), albeit it could punctually overcome the LPOC contribution (8 to 17 June). Peak discharges of the Rhone River up to 17 April clearly favour the LPOC contribution (Fig. 12a and b) when SPOC contributions are precisely found moderate. On the contrary, the phytoplankton contribution responds slowly to river nutrients loads so that their contribution turns maximal (9-11 June) when river runoffs weaken.

\subsection{Influence of terrestrial POM inputs on POC deposition}

A sensitivity test is carried out to evaluate the influence of terrestrial inputs on the total POC deposition on the Gulf of Lions shelf. The Rhone River inputs of all types of particulate organic matter (Dets and Det $t_{L}$ in the model, expressed in $\mathrm{C}, \mathrm{N}$, and $\mathrm{P}$ ) are switched off (hereafter "noPOM" simulation). The outputs of POC deposition on the shelf from the "Reference" simulation are then compared to the results of the "noPOM" simulation in terms of normalized differences $(\%)$. The map of cumulated differences during the study period (Fig. 14) shows a positive pattern in the close vicinity of the Rhone River mouth extending over $30 \mathrm{~km}$ until $200 \mathrm{~m}$ depth. The prodelta region is the main deposition area of terrestrial POC in the model, which is in agreement with numerous previous studies (Calmet and Fernandez, 1990; Durrieu de Madron et al., 2000; Tesi et al., 2007). On the contrary, one could expect that such positive influence of terrestrial POM inputs on POC deposition would concern the entire Gulf of Lions. However, a negative pattern of greater extension and same order of magnitude is clearly evidenced on the shelf from 50 to $500 \mathrm{~m}$ depth (Fig. 14). This pattern is of maximum intensity between 50 and $80 \mathrm{~m}$ depth alongshore, actually bordering the pattern of maximum POC deposition (Fig. 13). Such negative retroaction probably involves a reaction of the pelagic ecosystem dynamics to terrestrial POM inputs by the Rhone River.

The difference between the "Reference" and "noPOM" simulations was spatially averaged on the Gulf of Lions shelf (hereafter "signature") and its time evolution was confronted to that of Rhone River runoffs (Fig. 12a and c). Phytoplankton, small and large particulate organic carbon (hereafter PhytoC, SPOC, and LPOC) contributions are differentiated to further evaluate the key factors actually controlling the total organic carbon deposition.

Results first show an increasing contribution of terrestrial POC to the total POC deposition during peak discharges (Fig. 12a and c), which can be explained by the 
linear dependence between Rhone River runoffs and terrestrial POC inputs in the model (Sempéré et al., 2000). Terrestrial inputs appear responsible for a net $20 \%$ maximum increase of the total POC deposition at the whole shelf scale (Fig. 12c), split in maximal contributions of SPOC $(+5 \%)$ and LPOC $(+50 \%)$. We estimate that this corresponds to a $17 \%$ maximum contribution of terrestrial POM inputs to the total POC deposition. The positive pattern previously evidenced in the prodelta region (Fig. 14) is actually involved in this feature, as the total POC deposition in this region is mostly controlled by the terrestrial inputs from the Rhone River (Durrieu de Madron et al., 2000).

On the contrary, some biogeochemical mechanisms could be responsible for a negative influence of terrestrial inputs on POC deposition involving first, phytoplankton all along the study period (Fig. 12c); and second, particulate organic carbon (mainly SPOC) following peak discharges (Fig. 12a and $\mathrm{c}$ ).

The presence of terrestrial POM inputs clearly reduces phytoplankton deposition. This is in apparent contradiction with the important remineralization of terrestrial organic matter on the Gulf of Lions shelf (Durrieu de Madron et al., 2000) that should favour in fine the phytoplankton development. Therefore, a greater biomass of zooplankton exerting a stronger grazing pressure on phytoplankton could explain a lower deposition from phytoplankton origin (see Eq. A1).

The signature of total POC deposition generally turns negative several days after a peak discharge. Although weakly marked in early May after the peak discharge of 12 April, it appears clearly after the last peak of 23 May since the signature remains negative for more than one month from 26 May. This shift to negative signature is mainly attributable to the negative signatures of PhytoC (see above) but also of SPOC, and to a lesser extent of LPOC deposition. This behaviour actually explains the negative spatial pattern found on the western part of the shelf (Fig. 14). The reason for such signatures of SPOC and LPOC depositions may be found either in an increase of the grazing loss term or a decrease of the source terms, which are plankton mortality and zooplankton production of fecal pellets (see Eqs. A7 and A10).

Out of the prodelta area, the response of POC deposition to terrestrial inputs appears complex, suggesting a major role of biological processes, especially during a calm period following a period of peak discharge that stimulated biological activity (e.g. after 23 May, Fig. 12a). At the scale of the whole shelf, this effect is probably masked during peak discharge events transporting high contents of terrestrial inputs. This could explain that the negative impact of the first peak discharge of April is not visible since a new peak of terrestrial inputs arises a few days after.
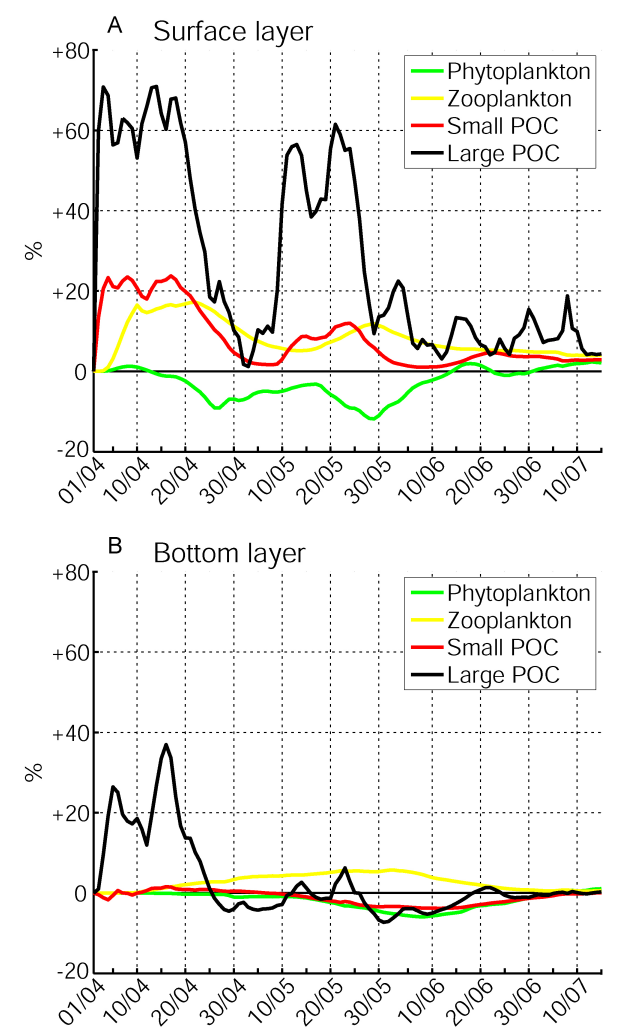

Fig. 15. Normalized differences (in \%) of phytoplankton (only microphytoplankton), zooplankton (all zooplankton size classes), large and small particulate organic carbon stocks between reference and "noPOM" simulations. Surface (A - 0-25 m depth) and bottom layers (B $-25 \mathrm{~m}$ to bottom) are considered separately for each stock.

\subsection{Influence of terrestrial POM inputs on POM contents in the water column}

The outputs of the "Reference" simulation in terms of phytoplankton (micro), zooplankton (micro + meso), and particulate organic carbon stocks are compared to those of the "noPOM" simulation (Fig. 15, positive values mean a positive impact of terrestrial inputs) considering separately the surface (0-25 m, Fig. 15a) and bottom layers ( $25 \mathrm{~m}$-seabed, Fig. 15b). As for the POC deposition analysis (see above), the differences corresponding to these stocks are averaged on the simulation domain and presented as a function of time. The key factors which likely control the fate of POC from the surface to sediment should finally arise from our analysis. In the ecosystem model, phytoplankton and zooplankton mainly fuel the pool of POC through mortality and egestion processes (see Eqs. A7 and A10). In turn, the zooplankton grazing controls the contents of phytoplankton POC in the water column (see also Eqs. A1 to A4). Zooplankton also participates with bacteria to the organic matter remineralization (see Eqs. A14 and A15), which benefits ultimately to phytoplankton. 

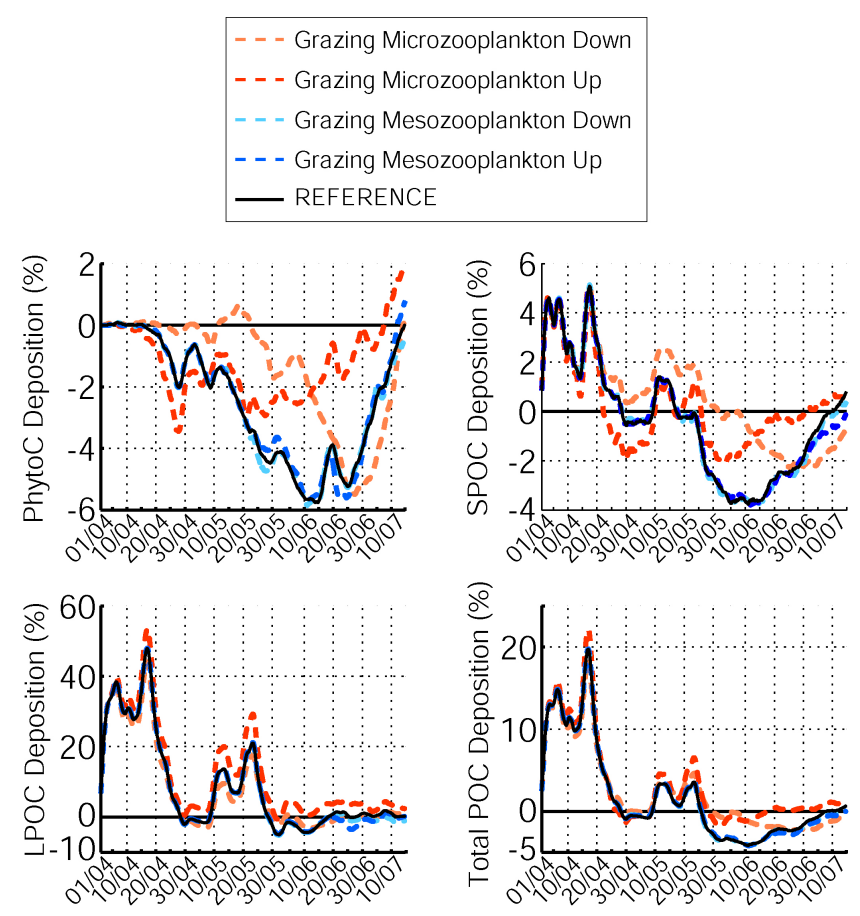

Fig. 16. Sensitivity analysis of the model results to micro- and mesozooplankton grazing rates $(\mathrm{UP}=+50 \%$ and $\mathrm{DOWN}=-50 \%$ of grazing rates reference), considering the normalized difference between reference and "noPOM" simulations (\%) of the daily particulate organic carbon deposition rates averaged on the Gulf of Lions shelf.

At the surface (Fig. 15a), the evolution of both SPOC and LPOC signatures follows the Rhone River runoffs (Fig. 12a) and reaches two maxima (1-18 April and 12-21 May) corresponding to peak discharges of the Rhone River. In the same way, the zooplankton signature exhibits two peaks (22 April and 30 May), actually following similar peaks of SPOC and LPOC signatures $(\sim 17$ April and $\sim 22$ May). As a consequence, the zooplankton dynamics in the 0-25 m layer appears mostly driven by SPOC dynamics (LPOC being not a food resource for zooplankton in the model).

The phytoplankton signature is different and exhibits a series of alternatively negative and slightly positive peaks. Primarily found positive, it increases in the same way that both zooplankton and POC signatures from 1 to 10 April. The remineralization rates of particulate organic matter are probably very high on the Gulf of Lions (Durrieu de Madron et al., 2000), and the phytoplankton would benefit from such an additional source of nutrients. This feature so emphasizes a positive influence exerted by terrestrial POM inputs on the phytoplankton growth through remineralization processes (bottom-up control). On the contrary, from 10 April to the end of the study, the phytoplankton signature exhibits alternatively negative and positive peaks opposed to those of zooplankton. The phytoplankton growth is probably still favoured by terrestrial inputs of organic matter. Neverthe- less, the zooplankton grazing pressure also increases (see above) and might finally end up controlling the phytoplankton growth through a usual top-down control.

In the bottom layer (Fig. 15b), the zooplankton signature is systematically positive all along the study period. Such signature seems primarily driven by a positive signature of food stocks near the bottom, namely phytoplankton and SPOC. The positive influence of terrestrial POM inputs on the zooplankton biomass therefore extends on the whole water column. The LPOC signature is clearly positive in the bottom layer during the Rhone River peaks discharge and that of SPOC is also positive from 10 April to 12 May. In the same way, the phytoplankton signature is found positive at the very beginning of the study period (1 to 10 April), most probably enhanced by remineralization processes of terrestrial POM, as already suggested at the surface. After this initial phase of positive signatures, both phytoplankton and SPOC signatures turn negative in the bottom layer until the end of the study period. According to this evolution pattern, zooplankton could be primarily influenced by terrestrial POM inputs and then control both phytoplankton and SPOC contents in the water column. In other words, zooplankton would respond to terrestrial POM inputs near the river mouth and, in turn, zooplankton would control the POM contents (mostly of marine origin) further on the shelf and ultimately the deposition rates. This effect of trophic cascading would therefore explain the negative pattern of POC deposition previously found on the shelf (Fig. 14).

The latter results crucially depend on the model parameters that control the large zooplankton grazing rates and biomass. We then processed a sensitivity analysis of our results to the micro- and mesozooplankton grazing rates ( $\pm 50 \%$ of the reference value). Figure 16 presents the results of this sensitivity analysis considering the difference of POC deposition rates averaged on the Gulf of Lions shelf between "Reference" and "noPOM" simulations (previously presented on Fig. 12c). The results remain weakly modified by a modification of the mesozooplankton grazing rate, but they appear more sensitive to the microzooplankton grazing rate. This somehow suggests a stronger control exerted by this zooplankton size class on the POC deposition rates in the model. An explanation for such feature can be actually found in both higher biomass and maximum grazing rate parameter for micro- than for mesozooplankton. Thus, a decrease of the microzooplankton grazing rate seems to reduce the feedback between zooplankton and POM terrestrial inputs. Nevertheless, the paradoxical negative signature following peak discharges from the Rhone River (see Sect. 4.2) appears consistent and thus ensures the robustness of our analysis.

\section{Discussion}

The ecosystem productivity of the Rhone River plume and the hydrodynamic environment of the Gulf of Lions are 
relatively well known (Naudin et al., 2001; Diaz et al., 2008; Estournel et al., 2003). However, the mechanisms that drive the deposition of particulate organic carbon on the Gulf of Lions shelf remain poorly addressed. The quantitative modelling tool is used in science to improve our understanding of the natural world (Oreskes, 2003). Thus, following a heuristic approach and beyond simply evaluating the deposition of organic carbon on the Gulf of Lions shelf during spring, our efforts focused on better understanding the key factors that actually control the organic carbon sedimentation on the shelf. By the modelling approach we developed, the roles of Rhone River inputs and plankton dynamics in the control of organic matter fluxes in the water column have been investigated. Our results consistently suggest an important role of zooplankton in controlling the organic carbon deposition on the shelf.

\subsection{Zooplankton control on POC deposition}

According to our results, the POC deposition on the Gulf of Lions shelf depends on the control exerted by zooplankton on the POM contents in the water column. Zooplankton is at the interface between river and marine environments and can be considered as a key energetic link in the food web of river plumes (Breed et al., 2004). The consumption of fresh marine phytoplankton, as well as organic detritus of terrestrial and marine origins, leads to increased zooplankton biomass in plume environments in agreement with previous observations (Turner and Tester, 1989; Dagg et al., 2004). In the Gulf of Lions, the spatial distribution of zooplankton biomass then appears mostly constrained by the enrichment effect of Rhone River inputs contrasting with the oligotrophic influence of the Northern Mediterranean Current (Gaudy et al., 2003).

The observations of Gaudy et al. (2003) show a dominating trophic mode of herbivory near the coast for zooplankton (both micro- and mesozooplankton size classes) then evolving to omnivory in the offshore areas of the Gulf of Lions. Hence, in the Rhone River plume, zooplankton has been shown to consume mostly "fresh" carbon fixed by marine phytoplankton, rather than POM of marine and terrestrial origin (Pagano et al., 1993; Gaudy et al., 2003). In fact, the feeding strategy of zooplankton probably responds to the carbon richness of surrounding waters since the shift from herbivorous to omnivorous feeding (carnivorous, detritivorous, etc.) has been evidenced between carbon-rich coastal water and Northern Mediterranean Current oligotrophic water at a fixed station off Marseille (Van Wambeke et al., 1996). On the whole, phytoplankton could provide up to $90 \%$ of the dietary carbon of mesozooplankton feeding in plume regions (Schlacher et al., 2009).

Then terrestrial organic matter would be of little direct nutritional importance to zooplankton in plume water. However, the study of Gaudy et al. (2003) also shows that zooplankton (both micro- and mesozooplankton) can punctually make an additional consumption of terrestrial POM to supply the necessary energy for its growth, especially during the spring period. In this study, a significant correlation between zooplankton biomass and POC contents at the scale of the whole gulf has been shown, suggesting a rather omnivorous trophic behaviour during this period. These observed features support our results of a significant consumption of terrestrial POM inputs by zooplankton in the river plume during the study period (Fig. 15).

According to our study, zooplankton is favoured by terrestrial POM inputs and high biological productivity within the plume. In turn, zooplankton reduces the phytoplankton and POC contents in the water column, and then the total POC deposition rates on the Gulf of Lions shelf. As already stated by Dagg et al. (2004), in marine areas under freshwater influence, the conversion of POM in living organisms through an omnivorous behaviour of zooplankton actually increases the retention of organic matter in the food web and bypasses the bacterial remineralization. Moreover, the observations of Pagano et al. (1993) and Van Wambeke et al. (1996) on the metabolic $\mathrm{O}: \mathrm{N}$ ratios measurements of mesozooplankton in the Rhone River plume area show a shift from herbivory within the plume layer to omnivory in marine water under the plume. These observations support our modelled results, which show an accentuated control of POC contents near the bottom by zooplankton.

\subsection{POC deposition on the shelf}

At the shelf scale, the organic carbon deposition is largely due to organic detritus (SPOC + LPOC) since their contribution is estimated to range from 82 to $92 \%$. The contribution of living organisms (microphytoplankton) finally remains limited at an average of $13 \%$ with a maximum of $17 \%$ under specific conditions. Moreover, the model could underestimate the POC contribution and overestimate the phytoplankton contribution (see Sect. 3.2.1).

At first order, the time evolution of the organic carbon deposition follows the river runoffs (Fig. 12a and b). This could be especially true for the prodelta area where the organic carbon deposition is mainly constituted of terrestrial material (Cathalot et al., 2010), mostly LPOC in the model. As highlighted by the results of our sensitivity analysis (Fig. 14) and in agreement with sedimentological data (Durrieu de Madron et al., 2000), terrestrial organic particles quickly sink on the prodelta area, remaining barely available for zooplankton consumption (Schlacher et al., 2009). Moreover, the phytoplankton growth is mostly inhibited near the river mouth (Naudin et al., 2001). For these reasons, the deposition of marine organic material is limited in this region.

From the results of our sensitivity analysis (see Sect. 4.2), we estimate that the contribution of terrestrial POM inputs to the total POC deposition is lower than $17 \%$ at the shelf scale. Thus, biological processes primarily enhanced by terrestrial inorganic matter inputs appear to mostly drive the 
POC deposition further on the Gulf of Lions shelf. The role of zooplankton, as highlighted by our results, is then likely to be significant. Nutrient loads induced by the Rhone River discharge first stimulate phytoplankton growth in the region of freshwater influence, enhancing high primary productivity and phytoplankton biomass (Naudin et al., 2001), as also observed in other plume regions (Dagg et al., 2004; Mallin et al., 2005). This results in the sedimentation of living phytoplankton as well as organic detritus produced via phytoplankton senescence. Terrestrial POM inputs and primary production also enhance zooplankton biomass through grazing processes. Primary and secondary productions are then favoured by high river runoffs. In that case, the senescence of both phytoplankton and zooplankton cells could finally fuel the pool of POM and increase the organic carbon deposition on the shelf. However, our results show that zooplankton communities are also favoured by high river runoffs and can finally consume both terrestrial inputs and marine production of POM before their deposition on the seabed. The retention of organic carbon in zooplankton is relatively increased during peak discharges, and biogenic elements from the Rhone River are then relatively more transferred in living organisms and less buried into shelf sediments. As a consequence, there is probably no linear relationship between river runoffs and organic carbon sedimentation within the shelf, out of the prodelta area at least. Given that high zooplankton biomass is favoured by high river discharge, the timing of peak discharges could also modulate the POC deposition on the shelf. Indeed, the fate of terrestrial inputs from a peak discharge of the Rhone River is likely to be different, depending on whether it occurs after a period of low or high river discharge.

According to our model study, the LSW system owing to their fertilizing ability in phosphorus (Diaz et al., 2008) could have a negative impact on the carbon deposition on the shelf. During the LSW life, trophic interactions within the plankton community involves occurrence of high phosphorus concentrations. These unusual concentrations in phosphorus result in the development of large phytoplankton that in turn enhances the development of large-sized zooplankton. According to our findings, zooplankton would then reduce the organic matter contents in the water column and ultimately the deposition on the shelf.

During high river discharge, the effective carbon deposition would be delayed toward the south-western exit of the shelf, or even further in the open sea and the Catalan shelf, through strong horizontal advection of zooplankton communities through canyons on the slope (Kouwenberg, 1994; Qiu et al., 2010). Out of the shelf, these populations could collapse due to a lack of prey availability and then reach deep sediments under organic detritus form. However, the depth of the seabed increases between the shelf and the open sea and this is likely to make less efficient the carbon burial in sediments. The zooplankton biomass could also fuel small pelagic fishes outside of the Gulf of Lion, such as anchovy and sardines mid-trophic species that were shown to play an important role within Mediterranean ecosystem as well as productive upwelling regions (Palomera et al., 2007; Cury et al., 2000).

\section{Conclusions}

A coupled hydrodynamic-biogeochemical modelling was carried out to understand the mechanisms responsible for the organic carbon deposition on the Gulf of Lions shelf in the North-Western Mediterranean Sea. A modelling approach was developed to represent the high level of complexity of the plankton ecosystem dynamics within the Rhone River plume area and further on the Gulf of Lions then ensuring a robust analysis. The calibration and validation of our model were led simultaneously from a thorough analysis of biogeochemical in situ data (BIOPRHOFI) in LSW lenses detached from the Rhone River plume. A robust validation of our model then ensured an accurate representation of the ecosystem dynamics along the salinity gradient from the Rhone River mouth to the LSW system formed on the Gulf of Lions.

Our results suggest that biological processes mostly control the POC deposition in the Gulf of Lions. The contribution of terrestrial POM inputs remains limited. Terrestrial POM inputs mainly sink on the prodelta area. However, there is a tight coupling between zooplankton and POM inputs through grazing processes on both terrestrial and marine material, especially microzooplankton. As consumers of particulate organic material including phytoplankton, bacteria and detritus of both terrestrial and marine origins, microand mesozooplankton significantly limits the organic carbon contents in the water column further on the Gulf of Lions shelf. Thus, peak discharges of the Rhone River increase the carbon deposition on the prodelta area and reduce it further offshore, thus increasing the gradient of carbon deposition on the shelf. The biogenic elements supplied by the Rhone River inputs are then exported further offshore through advection of zooplankton communities. Actually delaying the organic carbon deposition on the seabed toward the exit of the Gulf of Lions, this functioning could make less efficient the carbon burial in deep sediments and inversely increase the carbon retention in the food web toward higher trophic levels as small pelagic fishes.

Although based on a strong experimental background, our modelling approach still remains preliminary. A similar high resolution modelling study implemented on a larger domain (NW Mediterranean) could allow us to evaluate the out-ofshelf fate of the organic carbon produced within the Gulf of Lions. The advancement in computation capacities should enable the realization of such expensive simulation strategies in the future. The use of modelling tools to improve our understanding of the biological carbon pump in coastal areas and orientate future research efforts is anyway promising. 


\section{Appendix A}

\section{Model variables, equations and parameters}

Table A1. List of state variables.

\begin{tabular}{lll}
\hline State Variables & Description & Unit \\
\hline $\mathrm{NO}_{3}, \mathrm{NH}_{4}, \mathrm{PO}_{4}, \mathrm{SiO}_{4}$ & Nitrate, Ammonium, Phosphate, Silicate & $\mathrm{mmol} \mathrm{m}^{-3}$ \\
$\mathrm{XPhy}_{1}, \mathrm{XPhy}_{2}, \mathrm{XPhy}_{3}$ & $\begin{array}{l}\text { Pico-, nano-, microphytoplankton in X } \\
\mathrm{X}=\mathrm{C} \text { (carbon), } \mathrm{N} \text { (nitrogen), }\end{array}$ & $\mathrm{mmolX} \mathrm{m}^{-3}$ \\
& $\mathrm{P}$ (phosphorus) or Si (silica) & \\
$\mathrm{ChlPhy}_{1}, \mathrm{ChlPhy}_{2}, \mathrm{ChlPhy} 3$ & Pico-, nano-, microphytoplankton in chlorophyll & $\mathrm{mgChl} \mathrm{m}$ \\
$\mathrm{CZoo}_{1}, \mathrm{CZoo}_{2}, \mathrm{CZoo}_{3}$ & Nano-, micro- and mesozooplankton in carbon & $\mathrm{mmolC} \mathrm{m}^{-3}$ \\
$\mathrm{CBac}$ & Bacteria & $\mathrm{mmolC} \mathrm{m}^{-3}$ \\
$\mathrm{DOX}$ & Dissolved organic X, X=carbon, nitrogen, and phosphorus & $\mathrm{mmolX} \mathrm{m}^{-3}$ \\
$\mathrm{XDet}$ & Large (Y=L) and small (Y=S) particulate organic X, X=carbon, & $\mathrm{mmolX} \mathrm{m}^{-3}$ or \\
$\mathrm{PIM}$ & nitrogen, phosphorus, silica and chlorophyll (Chl) & $\mathrm{mgChl} \mathrm{m}^{-3}$ \\
& Particulate inorganic matter & $\mathrm{mg} \mathrm{m}^{-3}$ \\
\hline
\end{tabular}

Table A2. List of biogeochemical fluxes and functions.

\begin{tabular}{|c|c|c|}
\hline Symbol & Definition & Units \\
\hline $\mathrm{GPP}_{i}$ & Phytoplankton $i$ gross primary production & $\mathrm{mmolC} \mathrm{m}^{-3} \mathrm{~d}^{-1}$ \\
\hline $\operatorname{PAR}(z)$ & Photosynthetically active radiation at the depth $z$ & $\mathrm{~J} \mathrm{~m}^{-2} \mathrm{~d}^{-1}$ \\
\hline $\mathrm{PAR}_{\text {surf }}$ & Photosynthetically active radiation at the surface: $\operatorname{PAR}_{\text {surf }}=\operatorname{PAR}(z=0)$ & $\mathrm{J} \mathrm{m}^{-2} \mathrm{~d}^{-1}$ \\
\hline$\mu_{\mathrm{Phy}_{i}}^{\mathrm{NR}}$ & Phytoplankton $i$ maximal growth rate in nutrient-replete (NR) conditions & $d^{-1}$ \\
\hline$\mu_{\mathrm{Phy}_{i}}$ & Phytoplankton $i$ growth rate & $d^{-1}$ \\
\hline RespPhy $_{i}$ & Phytoplankton $i$ respiration rate & $\mathrm{mmolC} \mathrm{m}^{-3} \mathrm{~d}^{-1}$ \\
\hline $\mathrm{UptPhy}_{i, \mathrm{Nut}_{j}}$ & $\begin{array}{l}\text { Phytoplankton } i \text { uptake rate of nutrient } \mathrm{Nut}_{j} \text { where } \mathrm{Nut}_{1}=\mathrm{NO}_{3}, \mathrm{Nut}_{2}=\mathrm{NH}_{4} \text {, } \\
\mathrm{Nut}_{3}=\mathrm{PO}_{4}, \mathrm{Nut}_{4}=\mathrm{SiO}_{4}\end{array}$ & $\mathrm{mmol} \mathrm{m}^{-3} \mathrm{~d}^{-1}$ \\
\hline$V_{\mathrm{Phy}_{i}, \mathrm{X}}^{\max }$ & $\begin{array}{l}\text { Maximum carbon-specific uptake rate of phytoplankton } i \text {, where } \mathrm{X}=\text { nitrogen }(\mathrm{N}) \text {, } \\
\text { phosphorus }(\mathrm{P}) \text { or Silica }(\mathrm{Si})\end{array}$ & $\operatorname{mmolX~mmolC}{ }^{-1} \mathrm{~d}^{-1}$ \\
\hline $\mathrm{gml}_{i}$ & Growth multi-nutrient limitation function for phytoplankton $i$ & - \\
\hline$(\mathrm{X} / \mathrm{C})_{\mathrm{Phy}_{i}}$ & Phytoplankton internal X/C quota & $\operatorname{molX~molC}{ }^{-1}$ \\
\hline $\mathrm{Exu}_{i, \mathrm{X}}$ & Phytoplankton $i$ exudation rate of DOX, where $\mathrm{X}=$ carbon $(\mathrm{C}), \mathrm{N}, \mathrm{P}$ or $\mathrm{SiO}_{4}$ & $\mathrm{mmolX} \mathrm{m}^{-3} \mathrm{~d}^{-1}$ \\
\hline$f_{\mathrm{Xlim}^{\mathrm{Q}} \mathrm{Phy}_{i}}^{\mathrm{Q}}$ & Quota function for growth of phytoplankton $i$ & - \\
\hline$f_{\text {upt }_{\mathrm{X}, \mathrm{Phy}_{i}}^{\mathrm{Q}}}$ & Quota function for uptake of nutrient $\mathrm{X}$ by Phytoplankton $i$ & - \\
\hline Synth $_{i, \mathrm{Chl}}$ & Phytoplankton $i$ chlorophyll synthesis rate & $\mathrm{mgCh} l \mathrm{~m}^{-3} \mathrm{~d}^{-1}$ \\
\hline$\rho_{\mathrm{Phy}_{i}, \mathrm{Chl}}$ & Chlorophyll synthesis regulation term & $\mathrm{mgChl} \mathrm{mmolN}-1$ \\
\hline MortPhy $_{i, \mathrm{X}}$ & Phytoplankton $i$ senescence rate in $\mathrm{X}$, where $\mathrm{X}=\mathrm{C}, \mathrm{N}, \mathrm{P}, \mathrm{Si}$ or chlorophyll (Chl) & mmolX m ${ }^{-3} \mathrm{~d}^{-1}$ or $\mathrm{mgChl} \mathrm{m}^{-3} \mathrm{~d}^{-1}$ \\
\hline Graz $_{i, \mathrm{XPrey}}$ & Zooplankton $i$ grazing rate on XPrey, Prey $=\left[\mathrm{Phy}_{i}, \mathrm{Zoo}_{i}, \mathrm{Bac}\right.$, Dets $\left._{\mathrm{S}}, \mathrm{Det}_{\mathrm{L}}\right]$ & mmolX m ${ }^{-3} \mathrm{~d}^{-1}$ or $\mathrm{mgChl} \mathrm{m}^{-3} \mathrm{~d}^{-1}$ \\
\hline$(\mathrm{X} / \mathrm{C})_{\text {Prey }}$ & Prey internal $\mathrm{X} / \mathrm{C}$ quota & $\operatorname{molX~molC}-1$ \\
\hline SloppyFeed $_{i, \mathrm{X}}$ & Zooplankton $i$ sloppy feeding rate & $\operatorname{mmolX~m} m^{-3} \mathrm{~d}^{-1}$ \\
\hline Eges $_{i, \mathrm{X}}$ & Zooplankton $i$ egestion rate & $\operatorname{mmolX~m} m^{-3} \mathrm{~d}^{-1}$ \\
\hline GrowthZoo $_{i, \mathrm{C}}$ & Net zooplankton $i$ growth rate in carbon & \\
\hline ExcZoo $_{i, \mathrm{XNut}}$ & Zooplankton $i$ excretion rate of dissolved inorganic matter, $\mathrm{XNut}=\left[\mathrm{NH}_{4}, \mathrm{PO}_{4}\right]$ & $\operatorname{mmolX~m} m^{-3} \mathrm{~d}^{-1}$ \\
\hline FoodZoo $_{i, \mathrm{X}}$ & zooplankton food rate in $\mathrm{X}$ & $\operatorname{mmolX~m} m^{-3} d^{-1}$ \\
\hline$(\mathrm{X} / \mathrm{C})_{\mathrm{FoodZoo}_{i}}$ & Zooplankton food X/C quota & $\operatorname{molX~molC}{ }^{-1}$ \\
\hline $\operatorname{RespZoo~}_{i}$ & Zooplankton $i$ basal respiration rate & $\mathrm{mmolC} \mathrm{m}^{-3} \mathrm{~d}^{-1}$ \\
\hline $\operatorname{RespZoo}_{i}^{\text {add }}$ & Zooplankton $i$ additional respiration rate & $\mathrm{mmolC} \mathrm{m} \mathrm{m}^{-3} \mathrm{~d}^{-1}$ \\
\hline $\operatorname{MortZoo}_{i, \mathrm{X}}$ & Zooplankton $i$ mortality rate, $i=[1,2]$ & $\operatorname{mmolX~m} \mathrm{m}^{-3} \mathrm{~d}^{-1}$ \\
\hline PredZoo $_{3} \mathrm{x}$ & Zooplankton 3 predation rate & $\operatorname{mmolX~m} m^{-3} \mathrm{~d}^{-1}$ \\
\hline $\mathrm{UptBac}_{\mathrm{XNut}}^{\max }$ & Bacteria maximum uptake rate of dissolved inorganic matter, $\mathrm{XNut}=\left[\mathrm{NH}_{4}, \mathrm{PO}_{4}\right]$ & $\operatorname{mmolX~m} m^{-3} \mathrm{~d}^{-1}$ \\
\hline UptBacxNut & Bacteria uptake rate of dissolved inorganic matter, $\mathrm{XNut}=\left[\mathrm{NH}_{4}, \mathrm{PO}_{4}\right]$ & $\operatorname{mmolX~m} m^{-3} \mathrm{~d}^{-1}$ \\
\hline $\mathrm{UptBac}_{\mathrm{DOX}}$ & Bacteria uptake rate of dissolved organic $X$ & $\operatorname{mmolX~m} m^{-3} \mathrm{~d}^{-1}$ \\
\hline NBP & Net bacterial production & $\mathrm{mmolC} \mathrm{m}^{-3} \mathrm{~d}^{-1}$ \\
\hline$(\mathrm{X} / \mathrm{C})_{\text {FoodBac }}$ & Bacteria food $\mathrm{X} / \mathrm{C}$ quota & $\operatorname{molX} \operatorname{molC}^{-1}$ \\
\hline$(\mathrm{X} / \mathrm{C})_{\mathrm{DOM}}$ & Dissolved organic matter $\mathrm{X} / \mathrm{C}$ quota & $\operatorname{molX~molC}{ }^{-1}$ \\
\hline ExcBac XNut & Bacteria excretion rate of dissolved inorganic matter, $\mathrm{XNut}=\left[\mathrm{NH}_{4}, \mathrm{PO}_{4}\right]$ & $\operatorname{mmolX~m} m^{-3} \mathrm{~d}^{-1}$ \\
\hline RespBac & Bacteria respiration rate & $\mathrm{mmolC} \mathrm{m}^{-3} \mathrm{~d}^{-1}$ \\
\hline MortBac X & Bacteria mortality rate & $\operatorname{mmolX~m} m^{-3} \mathrm{~d}^{-1}$ \\
\hline Nitrif & Nitrification rate & mmolN m ${ }^{-3} \mathrm{~d}^{1}$ \\
\hline $\operatorname{Rem}_{X \text { Det }}$ & Remineralisation of $\mathrm{XDet} Y, \mathrm{Y}=[$ Small, Large $]$ & $\operatorname{mmolX~m}{ }^{-3} \mathrm{~d}^{1}$ \\
\hline$f^{T}$ & $\begin{array}{l}\text { Temperature function for phytoplankton growth, zooplankton grazing, bacterial } \\
\text { growth, remineralization and nitrification processes }\end{array}$ & - \\
\hline
\end{tabular}


Table A3. Equations of the biogeochemical rates of change of the state variables.

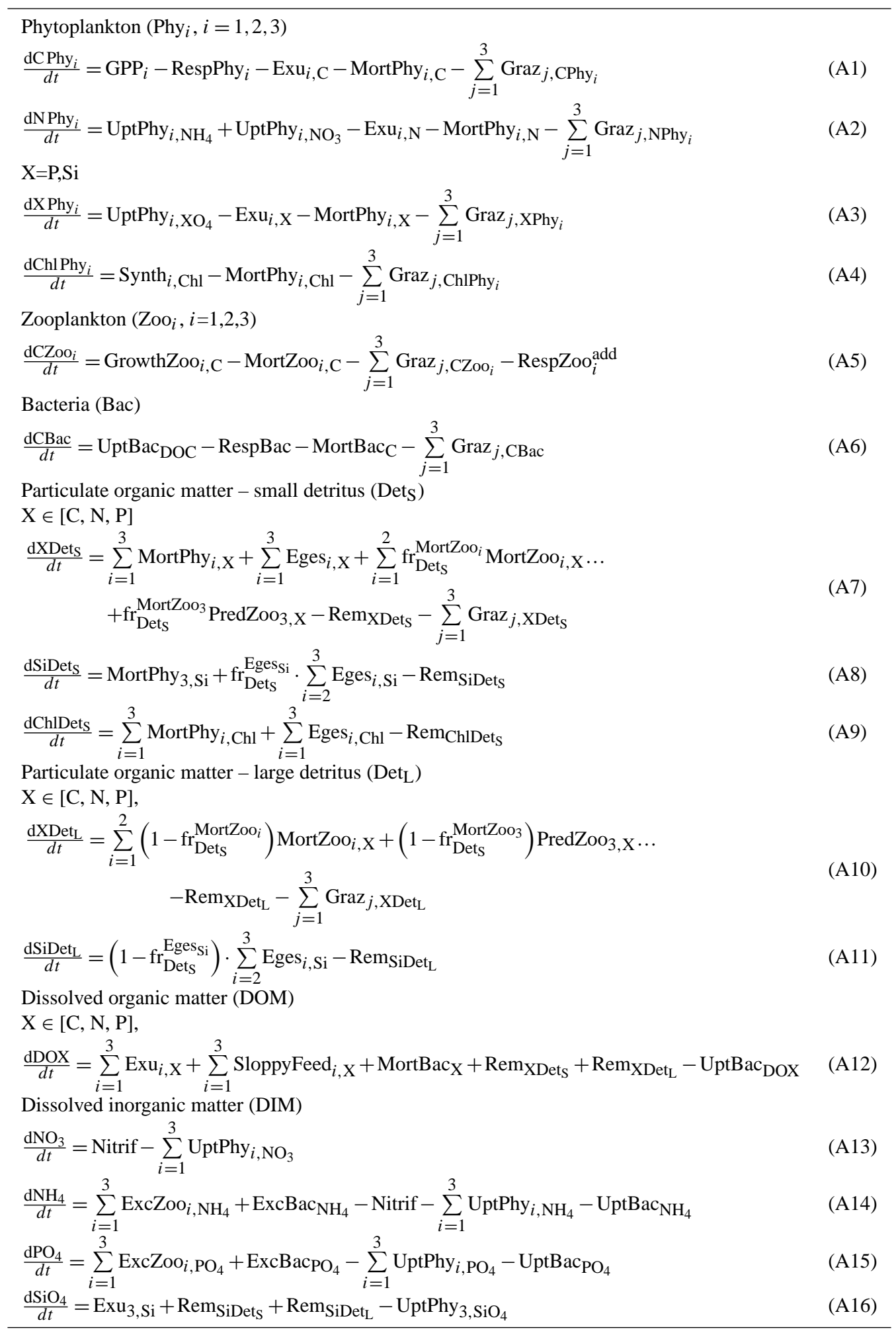


Table A4. Biogeochemical fluxes.

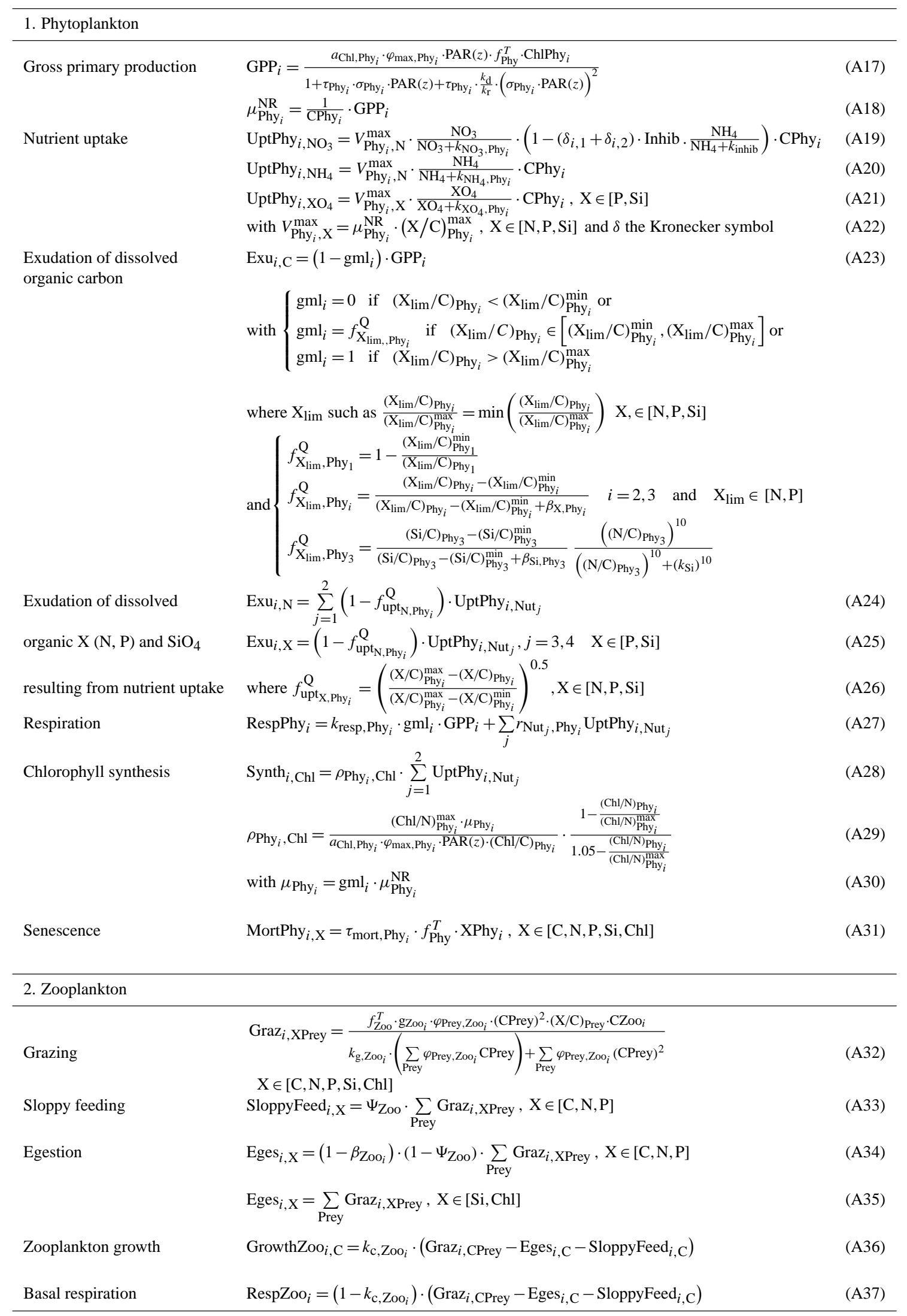


Table A4. Continued.

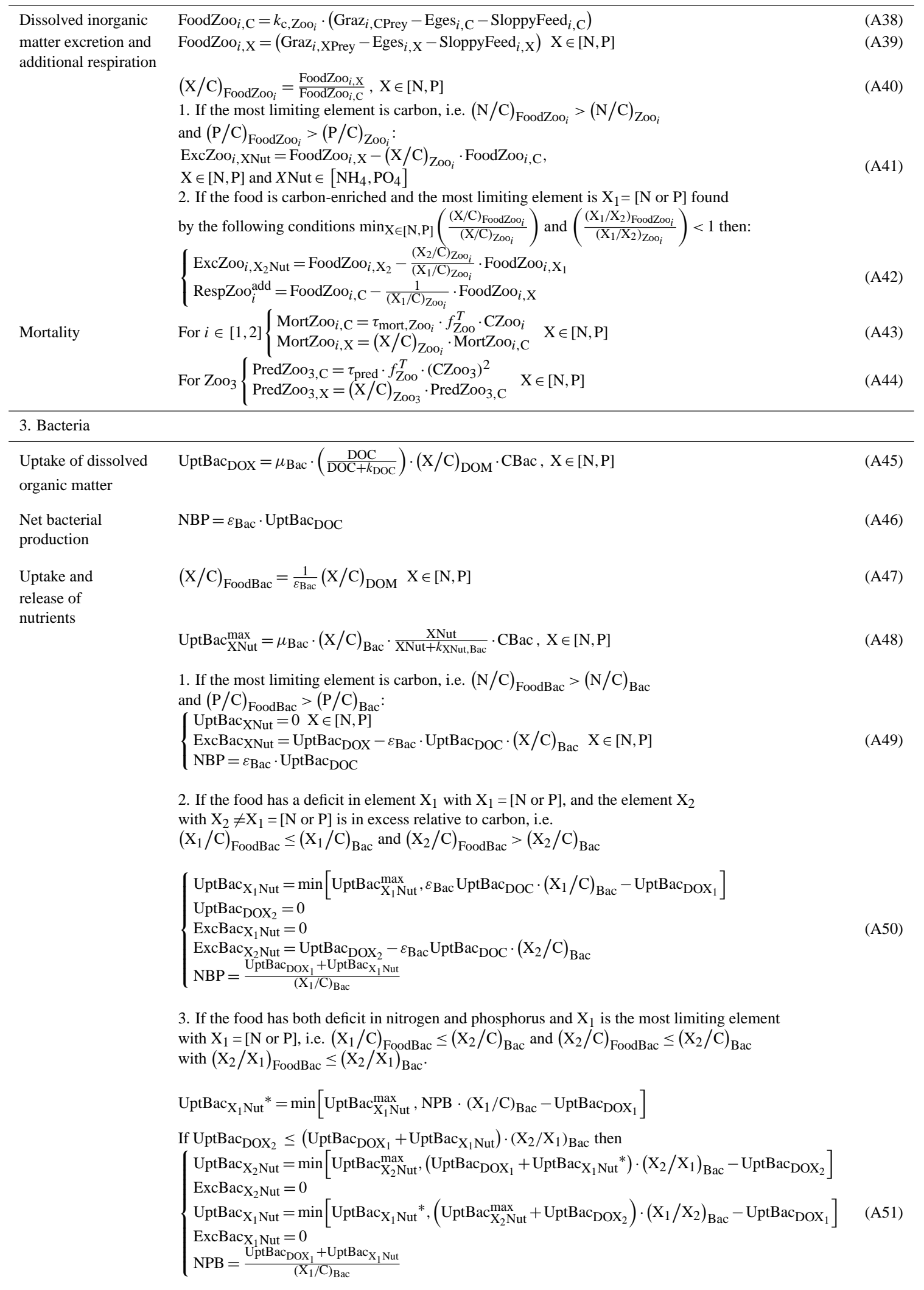


Table A4. Continued.

\begin{tabular}{|c|c|c|}
\hline else & $\left\{\begin{array}{l}\mathrm{UptBac}_{\mathrm{X}_{2} \mathrm{Nut}}=0 \\
\mathrm{ExcBac}_{\mathrm{X}_{2} \mathrm{Nut}}=\mathrm{UptBac}_{\mathrm{DOX}_{2}}-\left(\mathrm{UptBac}_{\mathrm{DOX}_{1}}+\mathrm{UptBac}_{\mathrm{X}_{1} \mathrm{Nut}}\right) \cdot\left(\mathrm{X}_{2} / \mathrm{X}_{1}\right) \\
\mathrm{UptBac}_{\mathrm{X}_{1} \text { Nut }}=\mathrm{UptBac}_{\mathrm{X}_{1} \mathrm{Nut}}{ }^{*} \\
\mathrm{ExcBac}_{\mathrm{X}_{1} \text { Nut }}=0 \\
\mathrm{NPB}=\frac{\mathrm{UptBac}_{\mathrm{DOX}_{1}}+\mathrm{UptBac}_{\mathrm{X}_{1} \text { Nut }}}{\left(\mathrm{X}_{1} / \mathrm{C}\right)_{\mathrm{Bac}}}\end{array}\right.$ & (A52) \\
\hline Respiration & $\operatorname{RespBac}=\mathrm{NBP} \cdot\left(\frac{1}{\varepsilon_{\mathrm{Bac}}}-1\right)$ & (A53) \\
\hline Mortality & MortBac $\mathrm{X}=\tau_{\mathrm{mort}, \mathrm{Bac}} \cdot f_{\mathrm{Bac}}^{T} \cdot(\mathrm{X} / \mathrm{C})_{\mathrm{Bac}} \cdot \mathrm{CBac}, \mathrm{X} \in[\mathrm{C}, \mathrm{N}, \mathrm{P}]$ & (A54) \\
\hline \multicolumn{3}{|l|}{ 4. Other process } \\
\hline Nitrification & Nitrif $=\tau_{\text {nitrif }} \cdot \mathrm{NH}_{4} \cdot f_{\text {Nitrif }}^{T} \cdot\left(1-\frac{\operatorname{PAR}(z)}{\operatorname{PAR}_{\text {surf }}}\right)$ & $(\mathrm{A} 55)$ \\
\hline Remineralization & $\operatorname{Rem}_{\mathrm{XDet}, \mathrm{L}}=\tau_{\mathrm{rem}, \mathrm{XDet}} \cdot \mathrm{XDet}_{\mathrm{S}, \mathrm{L}}$ & (A56) \\
\hline $\begin{array}{l}\text { Temperature function } \\
\text { for phytoplankton, } \\
\text { zooplankton } \\
\text { and bacterial growth, } \\
\text { and nitrification }\end{array}$ & $f^{T}(T)=Q_{10}\left(\frac{T-T^{\mathrm{REF}}}{10}\right), \quad Q_{10}$ and $T^{\mathrm{REF}}$ empirical constants & (A57) \\
\hline
\end{tabular}


Table A5. Biogeochemical parameters.

\begin{tabular}{|c|c|c|c|c|c|c|}
\hline \multirow{2}{*}{$\begin{array}{l}\text { Symbol } \\
\text { Phytoplankton }\end{array}$} & \multirow[t]{2}{*}{ Description } & \multirow[t]{2}{*}{ Unit } & \multicolumn{3}{|c|}{ Value } & \multirow[t]{2}{*}{ Reference } \\
\hline & & & Phy1 & Phy2 & Phy3 & \\
\hline$\varphi_{\max , \mathrm{Phy}_{j}}$ & Maximum quantum yield & $\mathrm{mmolC} \mathrm{J}^{-1}$ & $1.3 \mathrm{~d}-4$ & $1.5 \mathrm{~d}-4$ & $2.6 \mathrm{~d}-4$ & $1,2, \mathrm{c}$ \\
\hline $\mathrm{a}_{\mathrm{Chl}, \mathrm{Phy}}$ & Chl-specific absorption coeff. & $\mathrm{m}^{2} \mathrm{mgChl}^{-1}$ & 0.032 & 0.016 & 0.013 & $2, \mathrm{c}$ \\
\hline$\tau_{\mathrm{Phy}_{i}}$ & Renewal time of photosystems & $\mathrm{d}$ & $2.3 \mathrm{~d}-8$ & $3.5 \mathrm{~d}-8$ & $4.7 \mathrm{~d}-8$ & $3, \mathrm{c}$ \\
\hline$\sigma_{\mathrm{Phy}_{i}}$ & Cross-section of photosystems & $\mathrm{m}^{2} \mathrm{~J}^{-1}$ & 18 & 12 & 9 & $4,5, \mathrm{c}$ \\
\hline$k_{\mathrm{d}}$ & Dimensionless photoinhibition rate & - & $2.6 \mathrm{~d}-8$ & $2.6 \mathrm{~d}-8$ & $2.6 \mathrm{~d}-8$ & 6 \\
\hline$k_{\mathrm{r}}$ & Rate of repair of photoinhibition damaged PSII & $\mathrm{d}$ & $2.3 \mathrm{~d}-9$ & $2.3 \mathrm{~d}-9$ & $2.3 \mathrm{~d}-9$ & 6 \\
\hline$(\mathrm{N} / \mathrm{C})_{\mathrm{Phy}_{i}}^{\min }$ & Minimal internal N/C quota & molN molC ${ }^{-1}$ & 0.05 & 0.05 & 0.05 & $7,8,9$ \\
\hline$(\mathrm{N} / \mathrm{C})_{\mathrm{Phy}_{i}}^{\max _{i}}$ & Maximal internal N/C quota & molN molC ${ }^{-1}$ & $\mathbf{0 . 3 5}$ & $\mathbf{0 . 3 5}$ & 0.35 & $7,8,9$ \\
\hline$(\mathrm{P} / \mathrm{C})_{\mathrm{Phy}_{i}}^{\min _{i}}$ & Minimal internal $\mathrm{P} / \mathrm{C}$ quota & molP molC ${ }^{-1}$ & 0.004 & 0.002 & 0.002 & $8,9,10,11$ \\
\hline$(\mathrm{P} / \mathrm{C})_{\mathrm{Phy}_{i}}^{\max _{i}}$ & Maximal internal P/C quota & molP molC -1 & 0.005 & 0.005 & 0.010 & $8,9,10,11$ \\
\hline$(\mathrm{Si} / \mathrm{C})_{\mathrm{Phy}_{i}}^{\min _{i}}$ & Minimal internal Si/C quota & molSi molC ${ }^{-1}$ & - & - & 0.05 & 9,11 \\
\hline$(\mathrm{Si} / \mathrm{C})_{\mathrm{Phy}_{i}}^{\max _{i}}$ & Maximal internal Si/C quota & molSi molC ${ }^{-1}$ & - & - & 0.5 & 9,11 \\
\hline$(\mathrm{Chl} / \mathrm{N})_{\mathrm{Phy}}^{\max _{i}}$ & Maximal internal Chl/N quota & molChl molN ${ }^{-1}$ & 4.7 & 5.0 & 5.0 & $12,13, \mathrm{c}$ \\
\hline$Q_{\mathrm{Phy}}^{10}$ & Temperature coefficient & - & 2.0 & 2.0 & 2.0 & 14 \\
\hline$T_{\text {Phy }}^{\mathrm{REF}}$ & Reference temperature & ${ }^{\circ} \mathrm{C}$ & 20 & 20 & 20 & $\mathrm{c}$ \\
\hline$\beta_{\mathrm{N}, \mathrm{Phy}_{i}}$ & Nitrogen parameter for growth rate limitation & $\operatorname{molN~molC}-1$ & - & 0.0072 & 0.002 & $\mathrm{c}$ \\
\hline$\beta_{\mathrm{P}, \mathrm{Phy}_{i}}$ & Phosphorus parameter for growth rate limitation & $\mathrm{molP} \mathrm{molC}^{-1}$ & - & 0.0002 & 0.0005 & $\mathrm{c}$ \\
\hline$\beta_{\mathrm{Si} \mathrm{Phy}_{i}}$ & Silica parameter for growth rate limitation & molSi molC -1 & - & - & 0.004 & $\mathrm{c}$ \\
\hline$k_{\mathrm{Si}}$ & Nitrogen parameter for growth rate limitation by silica & $\mathrm{molN} \mathrm{molC}^{-1}$ & - & - & 0.1 & $\mathrm{c}$ \\
\hline$k_{\text {resp, }}$ Phy $_{i}$ & Respiration cost for growth & - & 0.3 & 0.25 & 0.2 & $13,15, \mathrm{c}$ \\
\hline$k_{\mathrm{NO}_{3}, \mathrm{Phy}_{i}}$ & Half saturation constant for $\mathrm{NO}_{3}$ & $\operatorname{mmolN~m}{ }^{-3}$ & 0.5 & 0.7 & 1.0 & $11,16,17, \mathrm{c}$ \\
\hline$k_{\mathrm{NH}_{4}, \mathrm{Phy}_{i}}$ & Half saturation constant for $\mathrm{NH}_{4}$ & $\mathrm{mmolN} \mathrm{m}^{-3}$ & 0.1 & 0.3 & 0.7 & $16,17, \mathrm{c}$ \\
\hline$k_{\text {inhib }}$ & Inhibition coefficient by $\mathrm{NH}_{4}$ & $\operatorname{mmolN~m}{ }^{-3}$ & 0.578 & 0.578 & - & 16 \\
\hline Inhib & Inhibition parameter by $\mathrm{NH}_{4}$ & - & 0.82 & 0.82 & - & 16 \\
\hline$k_{\mathrm{PO}_{4}, \mathrm{Phy}_{i}}$ & Half saturation constant for $\mathrm{PO}_{4}$ & $\mathrm{mmolP} \mathrm{m}^{-3}$ & 0.3 & 1.0 & 1.2 & $11,17,18, \mathrm{c}$ \\
\hline$k_{\mathrm{SiO}_{4}, \mathrm{Phy}_{i}}$ & Half saturation constant for $\mathrm{SiO}_{4}$ & $\mathrm{mmolSi} \mathrm{m}^{-3}$ & & & 1.2 & $11, \mathrm{c}$ \\
\hline$r_{\mathrm{NO}_{3}, \mathrm{Phy}_{i}}$ & Respiration cost for $\mathrm{NO}_{3}$ uptake & $\mathrm{molC} \mathrm{molN}^{-1}$ & 0.397 & 0.397 & 0.397 & 15 \\
\hline$r_{\mathrm{NH}_{4}, \mathrm{Phy}_{i}}$ & Respiration cost for $\mathrm{NH}_{4}$ uptake & $\mathrm{molC} \mathrm{molN}^{-1}$ & 0.198 & 0.198 & 0.198 & 15 \\
\hline$r_{\mathrm{PO}_{4}, \mathrm{Phy}_{i}}$ & Respiration cost for $\mathrm{PO}_{4}$ uptake & $\mathrm{molC} \mathrm{molP}^{-1}$ & 0.155 & 0.155 & 0.155 & 15 \\
\hline$r_{\mathrm{SiO}_{4}, \mathrm{Phy}_{i}}$ & Respiration cost for $\mathrm{SiO}_{4}$ uptake & $\mathrm{molC} \mathrm{molSi}^{-1}$ & & & 0.140 & 15 \\
\hline$\tau_{\text {mort, } \text { Phy }_{i}}$ & Phytoplankton $i$ senescence rate & $\mathrm{d}^{-1}$ & 0.16 & 0.13 & 0.10 & $19, \mathrm{c}$ \\
\hline$w_{\mathrm{s}, \text { Phy }_{i}}$ & Sinking rate of Phytoplankton $i$ & $\mathrm{md}^{-1}$ & & & 0.7 & $20, c$ \\
\hline Zooplankton & & & Zoo1 & Zoo2 & Zoo3 & \\
\hline$g_{\mathrm{Zoo}_{i}}$ & Maximum grazing rate & $\mathrm{d}^{-1}$ & 3.89 & 3.63 & 0.43 & $21,22, \mathrm{c}$ \\
\hline$k_{\mathrm{g}, \mathrm{Zoo}_{i}}$ & Half saturation constant & $\mathrm{mmolC} \mathrm{m}^{-3}$ & 5 & 8.5 & 20 & $23, \mathrm{c}$ \\
\hline$k_{\mathrm{c}, \mathrm{Zoo}_{i}}$ & Net growth efficiency & - & 0.8 & 0.8 & 0.8 & 24 \\
\hline$\Psi_{\text {Zoo }}$ & Sloppy feeding fraction & - & 0.23 & 0.23 & 0.23 & 24 \\
\hline$\beta_{\mathrm{Zoo}_{i}}$ & Assimilation efficiency & - & 0.6 & 0.6 & 0.6 & 24 \\
\hline$(\mathrm{N} / \mathrm{C})_{Z 00}$ & Internal N/C quota & $\operatorname{molN~molC}{ }^{-1}$ & 0.18 & 0.18 & 0.18 & $25,26,27$ \\
\hline$(\mathrm{P} / \mathrm{C})_{\mathrm{Zoo}_{i}}$ & Internal P/C quota & molP molC ${ }^{-1}$ & 0.013 & 0.013 & 0.013 & $25,26,27, \mathrm{c}$ \\
\hline$\tau_{\mathrm{mort}, \mathrm{Zoo}_{i}}$ & Natural mortality rate & $\mathrm{d}^{-1}$ & 0.112 & 0.086 & - & $\mathrm{c}$ \\
\hline$\tau_{\text {pred }}$ & Predation mortality rate & $\mathrm{m}^{3}(\mathrm{mmolC} \mathrm{d})^{-1}$ & - & - & 0.061 & $\mathrm{c}$ \\
\hline $\mathrm{fr}_{\text {Dets }}^{\text {Eges }_{S i}}$ & Ratio small/large particulate organic silica in residues of egestion & & - & 0.8 & 0.8 & $\mathrm{c}$ \\
\hline $\mathrm{fr}_{\text {Dets }}^{\text {MortZoo }_{i}}$ & Ratio small/large detritus in zooplankton loss term & - & 1 & 1 & 0.95 & $\mathrm{c}$ \\
\hline$Q_{700}^{10}$ & Temperature coefficient & - & 2.0 & 2.0 & 2.0 & 14 \\
\hline$T_{\mathrm{ZoO}}^{\mathrm{KOO}}$ & Reference temperature & ${ }^{\circ} \mathrm{C}$ & 20 & 20 & 20 & $\mathrm{c}$ \\
\hline
\end{tabular}


Table A5. Continued.

\begin{tabular}{|c|c|c|c|c|}
\hline \multicolumn{5}{|l|}{ Bacteria } \\
\hline$\mu_{\mathrm{Bac}}$ & Maximum DOC uptake & $\mathrm{d}^{-1}$ & 4.32 & $20, c$ \\
\hline$k_{\mathrm{DOC}}$ & Half-saturation for DOC uptake & $\mathrm{mmolC} \mathrm{m}^{-3}$ & 25 & 23 \\
\hline$k_{\mathrm{NH}_{4}, \mathrm{Bac}}$ & Half-saturation for $\mathrm{NH}_{4}$ uptake & $\mathrm{mmolN} \mathrm{m}^{-3}$ & 0.2 & $23, \mathrm{c}$ \\
\hline$k_{\mathrm{PO}_{4}, \mathrm{Bac}}$ & Half-saturation for $\mathrm{PO}_{4}$ uptake & $\mathrm{mmolP} \mathrm{m}^{-3}$ & 0.007 & $29, \mathrm{c}$ \\
\hline$(\mathrm{N} / \mathrm{C})_{\mathrm{Bac}}$ & Bacteria internal N/C quota & molN molC ${ }^{-1}$ & 0.232 & 26 \\
\hline$(\mathrm{P} / \mathrm{C})_{\mathrm{Bac}}$ & Bacteria internal $\mathrm{P} / \mathrm{C}$ quota & $\mathrm{molP} \mathrm{molC}^{-1}$ & 0.022 & 30 \\
\hline$\varepsilon_{\mathrm{Bac}}$ & Bacteria gross growth efficiency & - & 0.3 & $23, \mathrm{c}$ \\
\hline$\tau_{\text {mort,Bac }}$ & Bacteria mortality rate & $d^{-1}$ & 0.060 & 20 \\
\hline$Q_{\mathrm{Bac}}^{10}$ & Temperature coefficient & - & 2.95 & 26 \\
\hline$T_{\mathrm{Bac}}^{\mathrm{RE} E \mathrm{~F}}$ & Reference temperature & ${ }^{\circ} \mathrm{C}$ & 20 & c \\
\hline \multicolumn{5}{|c|}{ Non-living matter } \\
\hline$\tau_{\text {rem,CDet }}$ & Detritus remineralisation rate, $\mathrm{C}$ & $\mathrm{d}^{-1}$ & 0.04 & $23, \mathrm{c}$ \\
\hline$\tau_{\mathrm{rem}, \mathrm{NDet}}$ & Detritus remineralisation rate, $\mathrm{N}$ & $d^{-1}$ & 0.05 & $23, \mathrm{c}$ \\
\hline$\tau_{\text {rem,PDet }}$ & Detritus remineralisation rate, $\mathrm{P}$ & $d^{-1}$ & 0.06 & $29, \mathrm{c}$ \\
\hline$\tau_{\text {rem,ChlDet }}$ & Detritus remineralisation rate, $\mathrm{Chl}$ & $d^{-1}$ & 0.1 & $\mathrm{C}$ \\
\hline$\tau_{\text {rem, SiDet }}$ & Detritus remineralisation rate, $\mathrm{Si}$ & $d^{-1}$ & 0.005 & 19 \\
\hline$w_{\mathrm{s}, \text { Dets }}$ & Small detritus sinking rate & $\mathrm{md}^{-1}$ & 0.7 & 20 \\
\hline$w_{\mathrm{s}, \operatorname{Det}_{\mathrm{L}}}$ & Large detritus sinking rate & $\mathrm{md}^{-1}$ & 90 & $20, c$ \\
\hline$\tau_{\text {nitrif }}$ & Nitrification rate & $d^{-1}$ & 0.05 & $20, \mathrm{c}$ \\
\hline$Q_{\text {nitrif }}^{10}$ & Temperature coefficient for nitrification & - & 2.37 & 26 \\
\hline$T_{\text {nitrif }}^{\mathrm{REF}}$ & Reference temperature for nitrification & ${ }^{\circ} \mathrm{C}$ & 10 & $\mathrm{c}$ \\
\hline$Q_{\mathrm{rem}}^{10}$ & Temperature coefficient for remineralization & - & 2.95 & 26 \\
\hline$T_{\text {rem }}^{\mathrm{REF}}$ & Reference temperature for remineralization & ${ }^{\circ} \mathrm{C}$ & 20 & $\mathrm{c}$ \\
\hline
\end{tabular}


Table A6. Zooplankton grazing parameters.

\begin{tabular}{llllllll}
\hline$\varphi_{\mathrm{Prey}_{2} \mathrm{Zoo}_{i}}$ & Bacteria & $\mathrm{Phy}_{1}$ & $\mathrm{Phy}_{2}$ & $\mathrm{Phy}_{3}$ & $\mathrm{Zoo}_{1}$ & $\mathrm{Zoo}_{2}$ & sPOM \\
\hline $\mathrm{Zoo}_{1}$ & 0.35 & 0.65 & 0 & 0 & 0 & 0 & 0 \\
$\mathrm{Zoo}_{2}$ & 0.08 & 0.06 & 0.30 & 0.05 & 0.35 & 0.12 & 0.04 \\
$\mathrm{Zoo}_{3}$ & 0 & 0 & 0 & 0.5 & 0 & 0.45 & 0.05 \\
\hline
\end{tabular}

Parameters of the biogeochemical model and references: (c) Calibration; (1) Babin et al. (1996); (2) Claustre et al. (2005); (3) Laney et al. (2005); (4) Moore et al. (2003); (5) Gorbunov et al. (1999); (6) Oliver et al. (2003); (7) Heldal et al. (2003); (8) Riegman et al. (2000); (9) Geider et al. (1998); (10) Bertilsson et al. (2003); (11) Sarthou et al. (2005); (12) Geider et al. (1997); (13) Sondergaard and Theil-Nielsen (1997); (14) Baretta-Bekker et al. (1997); (15) Cannell and Thornley (2000); (16) Harrison et al. (1996); (17) Tyrrell and Taylor (1996); (18) Timmermans et al. (2005); (19) Fasham et al. (2006); (20) Lacroix and Grégoire (2002); (21) Christaki et al. (2002); (22) Nejstgaard et al. (1997); (23) Hansen et al. (1997); (24) Anderson and Pondaven (2003); (25) Eccleston-Parry and Leadbeater (1994); (26) Vichi et al. (2007); (27) Goldman et al. (1987); (28) Liu and Dagg (2003); (29) Thingstad et al. (1993); (30) Thingstad (2005)

\section{Appendix B}

\section{Model description and biogeochemical processes}

\section{B1 Phytoplankton processes}

The representation of the phytoplankton processes is derived from the model Eco3m presented and validated in Baklouti et al. (2006a, b). This version however was quite simple since it represented one generic compartment of phytoplankton expressed under carbon, nitrogen, and chlorophyll contents with potential limitation of phytoplankton growth by inorganic and organic nitrogen resource only. In the present work, this based-model has been extended to represent the different phytoplankton functional types computed in terms of carbon, nitrogen, phosphorus, silica (only for $\mathrm{Phy}_{3}$ ), and chlorophyll contents with potential multi-nutrient limitation for their growth. Moreover, the relative internal composition, i.e. the stoichiometry of each functional type, is considered as variable in accordance with field observations (e.g. Geider and La Roche, 2002; Sañudo-Wilhelmy et al., 2004); and then internal contents of carbon, nitrogen, phosphorus, and silica independently vary in a specified range for a given functional type according to the prevailing conditions in the nutrient resources at a given period.

The processes that drive the dynamic of biomass development of phytoplankton functional types are the gross primary production, autotrophic respiration, chlorophyll synthesis, exudation of dissolved organic carbon, the uptake of nutrient, exudation of dissolved organic matter following the uptake of nutrients and the senescence, e.g. including viral lyses (Tables A2, A3, A4). Other elements constituting phytoplankton $(\mathrm{N}, \mathrm{P}$, and $\mathrm{Si}$ ) are obtained from nutrient uptake. A nutrient deficit leads to the exudation of DOC. Exudation of assimilated nutrient is also possible under dissolved organic matter if there are surpluses of nitrogen, phosphorus, or silica relative to carbon. Another part of the fixed carbon is consumed by respiration and rejected under the $\mathrm{CO}_{2}$ form. A respiratory cost is counted due to the nutrient uptake. The chlorophyll synthesis is surely controlled by light, but this process is also affected by the nutrient resource in nitrogen that is required for the building of pigment-protein complexes in chloroplasts. The senescence of phytoplankton gives in fine some detritus of POM.

\section{B2 Zooplankton processes}

The zooplankton model is an adapted version of the stoichiometric model developed for heterotrophs by Anderson and Pondaven (2003) and applied in the Ligurian sea by Raick et al. (2005, 2006). The model developed by Raick et al. $(2005,2006)$ initially considered the cycles of carbon and nitrogen and the present work extended it to the cycles of phosphorus and silica. But the principles at the base of this model were preserved. For instance, the different zooplankton functional types are considered as having the ability to maintain constant their internal composition referring to some previous experimental works (e.g. Hessen, 1990; Urabe and Watanabe, 1992; Sterner and Robinson, 1994). Then the intensity of the excretion and respiration processes will depend on the imbalance in the elemental composition between their biomass and the ingested food. The grazing, egestion, sloppy feeding, excretion, respiration, mortality, and predation by higher trophic level are the main processes driving the dynamics of zooplankton biomass at each time step in the model.

Depending on the zooplankton type considered, zooplankton can ingest some different phytoplankton types, bacteria, organic detritus, and other categories of zooplankton and even feeds on its own group (cannibalism). The size criteria drives the pattern of grazing for a given zooplankton type, which preferentially consumes preys with a size smaller than one or two orders of magnitude (Parsons et al., 1984) according to a classical Holling II law (Gentleman et al., 2003). During grazing, a significant fraction of the consumed prey is not ingested by zooplankton and is directly released under dissolved organic matter; this is the process of "sloppy feeding" (Anderson and Williams, 1998). In the ingested fraction, a portion is egested (production of fecal pellets). A further part of ingested carbon is also respired and feeds the $\mathrm{CO}_{2}$ pool. Homeostatic regulation of the elemental composition is made via the excretion process and zooplankton then acts as remineralizers under certain trophic conditions by releasing dissolved inorganic matter (phosphate and ammonium). The mortality process is a linear term of the zooplankton content for the nano- and micro-zooplankton and a quadratic term for meso-zooplankton (Fasham et al., 2006). It produces particulate organic matter (small and large detritus). 


\section{B3 Bacteria and remineralization processes}

The representation of bacteria processes is an advanced version of the model developed in Anderson and Pondaven (2003) and also extended and implemented in the Ligurian sea by Raick et al. (2005, 2006). The latter version accounts for a limitation of bacterial growth by carbon and nitrogen availability only. We further add in the present study a potential control of growth by phosphorus availability that is a characteristic feature of pico-heterotrophs community in NW Mediterranean Sea (Thingstad et al., 1998). Bacteria first absorb dissolved organic matter but they can also assimilate nutrients (ammonium and/or phosphate) if DON and/or DOP are lacking. On the contrary, they can also act as remineralizers by excreting nutrients when they are carbonlimited compared to nitrogen and phosphorus, i.e. when the DOC:DON and/or DOC/DOP ratios are inferior to the C:N and/or P internal ratios (Kirchman et al., 2000). The excretion, the nutrient uptake, and respiration are processes that make possible the control by bacteria of their stoichiometry. The occurrence and the intensity of these processes enable to maintain constant the internal composition of picoheterotrophs. The processes that drive the dynamics of the bacteria compartment are the uptake of DOM and of nutrients, the excretion of nutrients, respiration, and mortality.

The process of remineralization of POM here stands for the hydrolysis activity of particle-attached bacterial community. We have chosen to represent this type of bacterial process in an implicit way contrary to other pico-heterotrophs processes because global knowledge on ecology and specific activity of the particle-attached bacteria is relatively still missing (Ghiglione et al., 2007). This process feeds DOM pool for CDet, NDet, PDet, and ChlDet and silicates for particles of biogenic silica. The rate of remineralization $\tau_{\text {rem,XDet }}$ is assumed to be depending on the element $\mathrm{X}$ considered for detritus but not on its mass.

\section{B4 Coupling between the hydrodynamic and the biogeochemical model}

Because an on-line coupling would have been computationally too expensive, simulations with the hydrodynamic model were first performed, storing daily averaged current, turbulent diffusion coefficient, and temperature. Then the biogeochemical model was run using the circulation model results as forcing functions, with a 2 -h time step.

The rate of change of the concentration $C$ of each biogeochemical state variable was the sum of a physical rate of change and the biogeochemical one detailed in Table A3.

The physical rate of the concentration $C$ was computed by using the advection-diffusion equation:

$$
\frac{\partial C}{\partial t}+\frac{\partial u C}{\partial x}+\frac{\partial v C}{\partial y}+\frac{\partial\left(w-w_{\mathrm{s}}\right) C}{\partial z}=-\frac{\partial F}{\partial z}+S
$$

where $u, v, w$ are the three components of the current velocity, $F$ is the vertical turbulent flux given by $K_{Z} \cdot \frac{\partial C}{\partial z}, K_{z}$ is the vertical diffusivity calculated by the hydrodynamic model, and $w_{\mathrm{s}}$ is the settling velocity. A positive definite, upwind advection scheme is used (with a corresponding diffusion in the direction of the $x$-component of the current, $u$, given by $\left.\frac{|u| \cdot \Delta x}{2}\right)$. $S$ represents the sources such as river inputs.

Light avaibility for the photosynthethis of phytoplankton is computed by distinguishing the parts of light penetrating in low and short wavelength as follows:

$\operatorname{PAR}(z)=\operatorname{PAR}(z=0)(1-$ albedo $)$

$$
\begin{aligned}
& \left(p_{1} \cdot \exp \left[-\int_{0}^{z} k_{1, \mathrm{w}}+k_{1, \mathrm{p}} \cdot \operatorname{ChlPhy}(z)+k_{1, \mathrm{~s}} \cdot \operatorname{PIM}(z)\right]+\ldots\right. \\
& \left(1-p_{1}\right) \cdot \exp \left[-\int_{0}^{z} k_{\mathrm{s}, \mathrm{w}}+k_{\mathrm{s}, \mathrm{p}} \cdot \operatorname{ChlPhy}(z)+k_{\mathrm{s}, \mathrm{s}} \cdot \operatorname{PIM}(z)\right. \\
& +0.0068 \cdot \operatorname{DOC}(z)-0.4579])
\end{aligned}
$$

where $\operatorname{PAR}(z=0)$, the photosynthetically available irradiance at the surface, is assumed to be $43 \%$ of the irradiance given by the meteorological ALADIN model. $z$ is the depth. The percent of reflected irradiance, i.e. albedo, is set to $0.05 . p_{1}$ is the percent of PAR with long wavelength, $k_{\mathrm{w}}$ is the background extinction coefficient of water, $k_{\mathrm{p}}$ is the extinction coefficient due to phytoplankton, and $k_{\mathrm{s}}$ is the extinction coefficient due to suspended inorganic matter. The indices "s" and "l" stand for short and long wavelengths, respectively. An empirical linear relationship, found in the Rhone River plume (J. Para, personal communication, 2010) between light absorption by CDOM and DOC contents in the short wavelength, is used.

Acknowledgements. We are deeply indebted to P. Marsaleix, D. Bonnet and D. Bottjer for the discussions which helped us to improve the model. This work was mainly funded by the French ANR (Agence Nationale de la Recherche) through the CHACCRA project (Climate and Human-induced Alterations in Carbon Cycling at the River-seA connection). The support of the SESAME project (Contract No. GOCE-2006-036949) from the sixth Framework Program of the European Commission is also acknowledged The BIOPRHOFI cruise was supported by the CNRS-INSU within the framework of the French Programme National d'Environnement Côtier (PNEC). We thank the captain and crew of the R/V Le Surott, but above all, experimenters on board or in the laboratory for providing us reliable measurements: L. Oriol, C. Courties, U. Christaki, P. Raimbault, W. H. Jeffrey, N. Garcia, J. L. Fuda, N. Batailler, B. Rivière and M. Abboudi.

Edited by: L. Bopp 


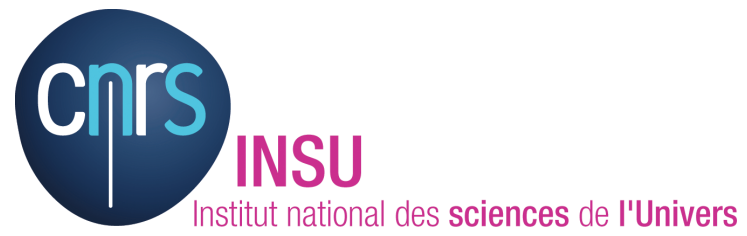

The publication of this article is financed by CNRS-INSU.

\section{References}

Allen, J. I., Holt, J. T., Blackford, J., and Proctor, R.: Error quantification of a high-resolution coupled hydrodynamicecosystem coastal-ocean model: Part 2. Chlorophylla, nutrients and SPM, J. Marine Syst., 68, 381-404, doi:10.1016/j.jmarsys.2007.01.005, 2007.

Aller, R. C.: Mobile deltaic and continental shelf muds as suboxic, fluidized bed reactors, Mar. Chem., 61, 143-155, 1998.

Anderson, T. R. and Pondaven, P.: Non-redfield carbon and nitrogen cycling in the Sargasso Sea: pelagic imbalances and export flux, Deep-Sea Res. Pt. 1, 50, 573-591, 2003.

Anderson, T. R. and Williams, P. J. L. B.: Modelling the Seasonal Cycle of Dissolved Organic Carbon at Station E1 in the English Channel, Estuar. Coast Shelf S., 46, 93-109, 1998.

Avril, B.: DOC dynamics in the northwestern Mediterranean Sea (DYFAMED site), Deep-Sea Res. Pt. 2, 49, 2163-2182, 2002.

Babin, M., Morel, A., Claustre, H., Bricaud, A., Kolber, Z., and Falkowski, P. G.: Nitrogen- and irradiance-dependent variations of the maximum quantum yield of carbon fixation in eutrophic, mesotrophic and oligotrophic marine systems, Deep-Sea Res. Pt. 1, 43, 1241-1272, 1996.

Babin, M., Stramski, D., Ferrari, G. M., Claustre, H., Bricaud, A., Obolensky, G., and Hoepffner, N.: Variations in the light absorption coefficients of phytoplankton, nonalgal particles, and dissolved organic matter in coastal waters around Europe, J. Geophys. Res., 108, 3211, doi:10.1029/2001JC000882, 2003.

Baklouti, M., Diaz, F., Pinazo, C., Faure, V., and Quéguiner, B.: Investigation of mechanistic formulations depicting phytoplankton dynamics for models of marine pelagic ecosystems and description of a new model, Prog. Oceanogr., 71, 1-33, 2006a.

Baklouti, M., Faure, V., Pawlowski, L., and Sciandra, A.: Investigation and sensitivity analysis of a mechanistic phytoplankton model implemented in a new modular numerical tool (Eco3M) dedicated to biogeochemical modelling, Prog. Oceanogr., 71, 34-58, 2006b.

Baretta-Bekker, J. G., Baretta, J. W., and Ebenhöh, W.: Microbial dynamics in the marine ecosystem model ERSEM II with decoupled carbon assimilation and nutrient uptake, J. Sea Res., 38, 195-211, 1997.

Bertilsson, S., Berglund, O., Karl, D. M., and Chisholm, S. W.: Elemental composition of marine Prochlorococcus and Synechococcus: Implications for the ecological stoichiometry of the sea, Limnol. Oceanogr., 48, 1721-1731, 2003.

Bianchi, M., Feliatra, and Lefevre, D.: Regulation of nitrification in the land-ocean contact area of the Rhone River plume (NW Mediterranean), Aquat. Microb. Ecol., 18, 301-312, 1999.

Bosc, E.: Variations saisonnières et interannuelles de la biomasse phytoplanctonique et de la production primaire en Méditerranée:
Evaluation et utilisation des données satellitales de couleur de l'océan, Ph.D. thesis, 2002.

Breed, G. A., Jackson, G. A., and Richardson, T. L.: Sedimentation, carbon export and food web structure in the Mississippi River plume described by inverse analysis, Mar. Ecol.-Prog. Ser., 278, 35-51, 2004.

Calmet, D. and Fernandez, J. M.: Caesium distribution in northwest Mediterranean seawater, suspended particles and sediments, Cont. Shelf. Res., 10, 895-913, 1990.

Cannell, M. G. R. and Thornley, J. H. M.: Nitrogen States in Plant Ecosystems: A Viewpoint, Ann. Bot.-London, 86, 1161-1167, 2000.

Cathalot, C., Rabouille, C., Pastor, L., Deflandre, B., Viollier, E., Buscail, R., Grémare, A., Treignier, C., and Pruski, A.: Temporal variability of carbon recycling in coastal sediments influenced by rivers: assessing the impact of flood inputs in the Rhône River prodelta, Biogeosciences, 7, 1187-1205, doi:10.5194/bg7-1187-2010, 2010.

Charles, F., Lantoine, F., Brugel, S., Chrétiennot-Dinet, M. J., Quiroga, I., and Rivière, B.: Seasonal survey of the phytoplankton biomass, composition and production in a littoral NW Mediterranean site, with special emphasis on the picoplanktonic contribution, Estuar. Coast Shelf S., 65, 199-212, 2005.

Christaki, U., Van Wambeke, F., Christou, E. D., Conan, P., and Gaudy, R.: Food web structure variability in the surface layer, at a fixed station influenced by the North Western Mediterranean Current, Hydrobiologia, 321, 145-153, 1996.

Christaki, U., Courties, C., Karayanni, H., Giannakourou, A., Maravelias, C., Kormas, K. A., and Lebaron, P.: Dynamic Characteristics of Prochlorococcus and Synechococcus Consumption by Bacterivorous Nanoflagellates, Microb. Ecol., 43, 341-352, 2002.

Christaki, U., Courties, C., Joux, F., Jeffrey, W. H., Neveux, J., and Naudin, J. J.: Community structure and trophic role of ciliates and heterotrophic nanoflagellates in Rhone River diluted mesoscale structures (NW Mediterranean Sea), Aquat. Microb. Ecol., 57, 263-277, 2009.

Claustre, H.: The trophic status of various oceanic provinces as revealed by phytoplankton pigment signatures, Limnol. Oceanogr., 39, 1206-1210, 1994.

Claustre, H., Babin, M., Merien, D., Ras, J., Prieur, L., Dallot, S., Prasil, O., Dousova, H., and Moutin, T.: Toward a taxon-specific parameterization of bio-optical models of primary production: A case study in the North Atlantic, J. Geophys. Res., 110, C07S12, doi:doi:10.1029/2004JC002634, 2005.

Cotner, J. B. and Wetzel, R. G.: Uptake of dissolved inorganic and organic phosphorus compounds by phytoplankton and bacterioplankton, Limnol. Oceanogr., 37, 232-243, 1992.

Cury, P., Bakun, A., Crawford, R. J. M., Jarre, A., Quinones, R. A., Shannon, L. J., and Verheye, H. M.: Small pelagics in upwelling systems: patterns of interaction and structural changes in "waspwaist” ecosystems, J. Mar. Sci., 57, 603-618, 2000.

Dagg, M. J., Benner, R., Lohrenz, S., and Lawrence, D.: Transformation of dissolved and particulate materials on continental shelves influenced by large rivers: plume processes, Cont. Shelf. Res., 24, 833-858, 2004.

Dagg, M. J., Bianchi, T., McKee, B., and Powell, R.: Fates of dissolved and particulate materials from the Mississippi river immediately after discharge into the northern Gulf of Mexico, USA, 
during a period of low wind stress, Cont. Shelf. Res., 28, 14431450, 2008.

Diaz, F., Raimbault, P., Boudjellal, B., Garcia, N., and Moutin, T.: Early spring phosphorus limitation of primary productivity in a NW Mediterranean coastal zone (Gulf of Lions), Mar. Ecol.Prog. Ser., 211, 51-62, 2001.

Diaz, F., Naudin, J. J., Courties, C., Rimmelin, P., and Oriol, L.: Biogeochemical and ecological functioning of the low-salinity water lenses in the region of the Rhone River freshwater influence, NW Mediterranean Sea, Cont. Shelf. Res., 28, 1511-1526, 2008.

Durrieu de Madron, X., Abassi, A., Heussner, S., Monaco, A., Aloisi, J. C., Radakovitch, O., Giresse, P., Buscail, R., and Kerhervé, P.: Particulate matter and organic carbon budgets for the Gulf of Lions (NW Mediterranean), Oceanol. Acta, 23, 717-730, 2000.

Eccleston-Parry, J. D. and Leadbeater, B. S. C.: The effect of longterm low bacterial density on the growth kinetics of three marine heterotrophic nanoflagellates, J. Exp. Mar. Biol. Ecol., 177, 219233, 1994

Estournel, C., Kondrachoff, V., Marsaleix, P., and Vehil, R.: The plume of the Rhone: numerical simulation and remote sensing, Cont. Shelf. Res., 17, 899-924, 1997.

Estournel, C., Broche, P., Marsaleix, P., Devenon, J. L., Auclair, F., and Vehil, R.: The Rhone River Plume in Unsteady Conditions: Numerical and Experimental Results, Estuar. Coast Shelf S., 53, 25-38, 2001.

Estournel, C., Durrieu de Madron, X., Marsaleix, P., Auclair, F., Julliand, C., and Vehil, R.: Observation and modeling of the winter coastal oceanic circulation in the Gulf of Lion under wind conditions influenced by the continental orography (FETCH experiment), J. Geophys. Res., 108, 8059, doi:10.1029/2001JC000825, 2003.

Fasham, M. J. R., Flynn, K. J., Pondaven, P., Anderson, T. R., and Boyd, P. W.: Development of a robust marine ecosystem model to predict the role of iron in biogeochemical cycles: A comparison of results for iron-replete and iron-limited areas, and the SOIREE iron-enrichment experiment, Deep-Sea Res. Pt. 1, 53, 333-366, 2006.

Ferrier-Pagès, C. and Rassoulzadegan, F.: Seasonal impact of the microzooplankton on pico-and nanoplankton growth rates in the northwest Mediterranean Sea, Mar. Ecol.-Prog. Ser., 108, 283294, 1994.

Gao, S. and Wang, Y. P.: Changes in material fluxes from the Changjiang River and their implications on the adjoining continental shelf ecosystem, Cont. Shelf. Res., 28, 1490-1500, 2008.

Gaudy, R., Pagano, M., and Lochet, F.: Zooplankton feeding on seston in the Rhone River plume area (NW Mediterranean Sea) in May 1988, Hydrobiologia, 207, 241-249, 1990.

Gaudy, R., Youssara, F., Diaz, F., and Raimbault, P.: Biomass, metabolism and nutrition of zooplankton in the Gulf of Lions (NW Mediterranean), Oceanol. Acta, 26(4), 357-372, 2003.

Geider, R. and La Roche, J.: Redfield revisited: variability of C:N:P in marine microalgae and its biochemical basis, Eur. J. Phycol., 37, 1-17, 2002.

Geider, R. J., MacIntyre, H. L., and Kana, T. M.: Dynamic model of phytoplankton growth and acclimation: Responses of the balanced growth rate and the chlorophyll a:carbon ratio to light, nutrient-limitation and temperature, Mar. Ecol.-Prog. Ser., 143,
187-200, 1997.

Geider, R. J., Macintyre, H. L., Graziano, L. M., and McKay, R. M. L.: Responses of the photosynthetic apparatus of Dunaliella tertiolecta (Chlorophyceae) to nitrogen and phosphorus limitation, Eur. J. Phycol., 33, 315-332, 1998.

Gentleman, W., Leising, A., Frost, B., Strom, S., and Murray, J.: Functional responses for zooplankton feeding on multiple resources: a review of assumptions and biological dynamics, Deep-Sea Res. Pt. 2, 50, 2847-2875, 2003.

Ghiglione, J. F., Mevel, G., Pujo-Pay, M., Mousseau, L., Lebaron, P., and Goutx, M.: Diel and Seasonal Variations in Abundance, Activity, and Community Structure of Particle-Attached and Free-Living Bacteria in NW Mediterranean Sea, Microb. Ecol., 54, 217-231, 2007.

Gilbes, F., Müller-Karger, F. E., and Del Castillo, C. E.: New evidence for the West Florida Shelf Plume, Cont. Shelf. Res., 22, 2479-2496, 2002.

Goldman, J. G., Caron, D. A., and Dennett, M. R.: Nutrient cycling in a microflagellate food chain: IV. Phytoplanktonmicroflagellate interactions, Mar. Ecol.-Prog. Ser., 38, 75-87, 1987.

Gomez, F. and Gorsky, G.: Annual microplankton cycles in Villefranche Bay, Ligurian Sea, NW Mediterranean, J. Plankton Res., 25, 323-339, 2003.

Gorbunov, M. Y., Kolber, Z. S., and Falkowski, P. G.: Measuring photosynthetic parameters in individual algal cells by Fast Repetition Rate fluorometry, Photosynth. Res., 62, 141-153, 1999.

Got, H. and Aloisi, J. C.: The Holocene sedimentation on the Gulf of Lions margin: a quantitative approach, Cont. Shelf. Res., 10, 841-855, 1990.

Green, R., Bianchi, T. S., Dagg, M. J., Walker, N. D., and Breed, G. A.: An organic carbon budget for the Mississippi River turbidity plume and plume contributions to air-sea $\mathrm{CO}_{2}$ fluxes and bottom water hypoxia, Estuar. Coast., 29, 579-597, 2006.

Grégoire, M., Soetaert, K., Nezlin, N., and Kostianov, A.: Modeling the nitrogen cycling and plankton productivity in the Black Sea using a three-dimensional interdisciplinary model, J. Geophys. Res., 109, C05007, doi:10.1029/2001JC001014, 2004.

Hansen, P. J., Bjørnsen, P. K., and Hansen, B. W.: Zooplankton grazing and growth: Scaling within the 2-2,000- III body size range, Limnol. Oceanogr., 42, 687-704, 1997.

Harrison, W. G., Harris, L. R., and Irwin, B. D.: The kinetics of nitrogen utilization in the oceanic mixed layer: Nitrate and ammonium interactions at nanomolar concentrations, Limnol. Oceanogr., 41, 16-32, 1996.

Heldal, M., Scanlan, D. J., Norland, S., Thingstad, F., and Mann, N. H.: Elemental composition of single cells of various strains of marine Prochlorococcus and Synechococcus using X-ray microanalysis, Limnol. Oceanogr., 48, 1732-1743, 2003.

Herrmann, M.: Prix Prud'homme 2010: "La formation d'eau dense en Méditerranée: interactions d'échelles, changement climatique et écosystèmes", La Météorologie, 70, 1-10, 2010.

Hessen, D. O.: Carbon, nitrogen and phosphorus status in Daphnia at varying food conditions, J. Plankton Res., 12, 1239-1249, 1990.

James, I. D.: Advection schemes for shelf sea models, J. Marine Syst., 8, 237-254, 1996.

Joux, F., Servais, P., Naudin, J. J., Lebaron, P., Oriol, L., and Courties, C.: Distribution of Picophytoplankton and 
bacterioplankton along a river plume gradient in the Mediterranean sea, Vie Milieu, 55, 197-208, 2005.

Joux, F., Jeffrey, W. H., Abboudi, M., Neveux, J., Pujo-Pay, M., Oriol, L., and Naudin, J. J.: Ultraviolet Radiation in the Rhône River Lenses of Low Salinity and in Marine Waters of the Northwestern Mediterranean Sea: Attenuation and Effects on Bacterial Activities and Net Community Production, Photochem. Photobiol., 85, 783-793, 2009.

Kirchman, D. L., Meon, B., Cottrell, M. T., Hutchins, D. A., Weeks, D., and Bruland, K. W.: Carbon versus iron limitation of bacterial growth in the California upwelling regime, Limnol. Oceanogr., 45, 1681-1688, 2000.

Kouwenberg, J. H. M.: Copepod Distribution in Relation to Seasonal Hydrographics and Spatial Structure in the North-western Mediterranean (Golfe du Lion), Estuar. Coast Shelf S., 38, 6990, 1994.

Lacroix, G. and Grégoire, M.: Revisited ecosystem model (MODECOGeL) of the Ligurian Sea: seasonal and interannual variability due to atmospheric forcing, J. Marine Syst., 37, 229-258, 2002.

Laney, S. R., Letelier, R. M., and Abbott, M. R.: Parameterizing the natural fluorescence kinetics of Thalassiosira weissflogii, Limnol. Oceanogr., 50, 1499-1510, 2005.

Le Quéré, C., Harrison, S. P., Prentice, I. C., Buitenhuis, E. T., Aumont, O., Bopp, L., Claustre, H., Cotrim Da Cunha, L., Geider, R., Giraud, X., Klaas, C., Kohfeld, K. E., Legendre, L., Manizza, M., Platt, T., Rivkin, R. B., Sathyendranath, S., Uitz, J., Watson, A. J., and Wolf-Gladrow, D.: Ecosystem dynamics based on plankton functional types for global ocean biogeochemistry models, Glob. Change Biol., 11, 2016-2040, 2005.

Leblanc, K., Quéginer, B., Garcia, N., Rimmelin, P., and Raimbault, P.: Silicon cycle in the NW Mediterranean Sea: seasonal study of a coastal oligotrophic site, Oceanol. Acta, 26, 339-355, 2003.

Lefevre, D., Minas, H. J., Minas, M., Robinson, C., Williams, P. J. L. B., and Woodward, E. M. S.: Review of gross community production, primary production, net community production and dark community respiration in the Gulf of Lions, Deep-Sea Res. Pt. 2, 44, 801-819, 1997.

Levy, M., Mémery, L., and André, J. M.: Simulation of primary production and export fluxes in the Northwestern Mediterranean Sea, J. Mar. Res., 56, 197-238, 1998.

Liu, H. and Dagg, M.: Interactions between nutrients, phytoplankton growth, and micro- and mesozooplankton grazing in the plume of the Mississippi River, Mar. Ecol.-Prog. Ser., 258, 3142, 2003.

Lohrenz, S. E., Redalje, D. G., Cai, W. J., Acker, J., and Dagg, M.: A retrospective analysis of nutrients and phytoplankton productivity in the Mississippi River plume, Cont. Shelf. Res., 28, 1466-1475, 2008.

Ludwig, W., Dumont, E., Meybeck, M., and Heussner, S.: River discharges of water and nutrients to the Mediterranean and Black Sea: Major drivers for ecosystem changes during past and future decades?, Prog. Oceanogr., 80, 199-217, 2009.

Mallin, M. A., Cahoon, L. B., and Durako, M. J.: Contrasting foodweb support bases for adjoining river-influenced and non-river influenced continental shelf ecosystems, Estuar. Coast. Shelf S., 62, 55-62, 2005.

Marsaleix, P., Estournel, C., Kondrachoff, V., and Vehil, R.: A numerical study of the formation of the Rhône River plume, J. Ma- rine Syst., 14, 99-115, 1998.

Marsaleix, P., Auclair, F., Floor, J., Herrmann, M., Estournel, C., Pairaud, I., and Ulses, C.: Energy conservation issues in sigmacoordinate free-surface ocean models, Ocean Modell., 20, 6189, 2008.

Marty, J. C. and Chiavérini, J.: Hydrological changes in the Ligurian Sea (NW Mediterranean, DYFAMED site) during 19952007 and biogeochemical consequences, Biogeosciences, 7, 2117-2128, doi:10.5194/bg-7-2117-2010, 2010.

Marty, J. C., Chiavérini, J., Pizay, M. D., and Avril, B.: Seasonal and interannual dynamics of nutrients and phytoplankton pigments in the western Mediterranean Sea at the DYFAMED timeseries station (1991-1999), Deep-Sea Res. Pt. 2, 49, 1965-1985, 2002.

Mitra, A.: Are closure terms appropriate or necessary descriptors of zooplankton loss in nutrient-phytoplankton-zooplankton type models?, Ecol. Model., 220, 611-620, 2009.

Moore, C. M., Suggett, D., Holligan, P. M., Sharples, J., Abraham, E. R., Lucas, M. I., Rippeth, T. P., Fisher, N. R., Simpson, J. H., and Hydes, D. J.: Physical controls on phytoplankton physiology and production at a shelf sea front: a fast repetition-rate fluorometer based field study, Mar. Ecol.-Prog. Ser., 259, 29-45, 2003.

Morel, A. and André, J. M.: Pigment Distribution and Primary Production in the Western Mediterranean as Derived and Modeled From Coastal Zone Color Scanner Observations, J. Geophys. Res., 96, 12685-12698, 1991.

Moutin, T., Raimbault, P., Golterman, H., and Coste, B.: The input of nutrients by the Rhône river into the Mediterranean Sea: recent observations and comparison with earlier data, Hydrobiologia, 373-374, 237-246, 1998.

Moutin, T., Thingstad, T. F., Van Wambeke, F., Marie, D., Slawyk, G., Raimbault, P., and Claustre, H.: Does competition for nanomolar phosphate supply explain the predominance of the cyanobacterium Synechococcus?, Limnol. Oceanogr., 47, 15621567, 2002.

Naudin, J. J., Cauwet, G., Chrétiennot-Dinet, M. J., Deniaux, B., Devenon, J. L., and Pauc, H.: River Discharge and Wind Influence Upon Particulate Transfer at the Land-Ocean Interaction: Case Study of the Rhone River Plume, Estuar. Coast Shelf S., 45, 303-316, 1997.

Naudin, J. J., Cauwet, G., Fajon, C., Oriol, L., Terzic, S., Devenon, J. L., and Broche, P.: Effect of mixing on microbial communities in the Rhone River plume, J. Marine Syst., 28, 203-227, 2001.

Nejstgaard, J. C., Gismervik, I., and Solberg, P. T.: Feeding and reproduction by Calanus finmarchicus, and microzooplankton grazing during mesocosm blooms of diatoms and the coccolithophore Emiliania huxleyi, Mar. Ecol.-Prog. Ser., 147, 197217, 1997.

Neveux, J. and Lantoine, F.: Spectrofluorometric assay of chlorophylls and phaeopigments using the least squares approximation technique, Deep-Sea Res. Pt. 1, 40, 1747-1765, 1993.

Oliver, R. L., Whittington, J., Lorenz, Z., and Webster, I. T.: The influence of vertical mixing on the photoinhibition of variable chlorophyll a fluorescence and its inclusion in a model of phytoplankton photosynthesis, J. Plankton Res., 25, 1107-1129, 2003.

Oreskes, N.: The role of quantitative models in science, in: Models in Ecosystem Science, edited by: Canham, C. D., Cole, J. J., Lauenroth, Wi, K., Princeton, 13-31, 2003. 
Pagano, M., Gaudy, R., Thibault, D., and Lochet, F.: Vertical Migrations and Feeding Rhythms of Mesozooplanktonic Organisms in the Rhône River Plume Area (North-west Mediterranean Sea), Estuar. Coast. Shelf S., 37, 251-269, 1993.

Palomera, I., Olivar, M. P., Salat, J., Sabatés, A., Coll, M., Garcia, A., and Morales-Nin, B.: Small pelagic fish in the NW Mediterranean Sea: An ecological review, Prog. Oceanogr., 74, 377-396, 2007.

Para, J., Coble, P. G., Charrière, B., Tedetti, M., Fontana, C., and Sempéré, R.: Fluorescence and absorption properties of chromophoric dissolved organic matter (CDOM) in coastal surface waters of the northwestern Mediterranean Sea, influence of the Rhône River, Biogeosciences, 7, 4083-4103, doi:10.5194/bg-74083-2010, 2010.

Parsons, T., Takahashi, M., and Hargrave, B.: Biological Oceanographic Processes, third edn., Pergamon Press, 1984.

Petrenko, A., Dufau, C., and Estournel, C.: Barotropic eastward currents in the western Gulf of Lion, north-western Mediterranean Sea, during stratified conditions, J. Marine Syst., 74, 406428, 2008.

Polimene, L., Pinardi, N., Zavatarelli, M., and Colella, S.: The Adriatic Sea ecosystem seasonal cycle: Validation of a threedimensional numerical model, J. Geophys. Res., 111, C03S19, doi:10.1029/2005JC003260, 2006.

Pujo-Pay, M. and Conan, P.: Seasonal variability and export of dissolved organic nitrogen in the northwestern Mediterranean Sea, J. Geophys. Res., 108, 3188, doi:10.1029/2000JC000368, 2003.

Pujo-Pay, M., Conan, P., Joux, F., Oriol, L., Naudin, J. J., and Cauwet, G.: Impact of phytoplankton and bacterial production on nutrient and DOM uptake in the Rhône River plume (NW Mediterranean), Mar. Ecol.-Prog. Ser., 315, 43-54, 2006.

Qiu, Z. F., Doglioli, A. M., Hu, Z. Y., Marsaleix, P., and Carlotti, F.: The influence of hydrodynamic processes on zooplankton transport and distributions in the North Western Mediterranean: Estimates from a Lagrangian model, Ecol. Model., 221, 2816-2827, 2010.

Quintana-Seguí, P., Habets, F., and Martin, E.: Comparison of past and future Mediterranean high and low extremes of precipitation and river flow projected using different statistical downscaling methods, Nat. Hazards Earth Syst. Sci., 11, 1411-1432, doi:10.5194/nhess-11-1411-2011, 2011.

Radach, G. and Moll, A.: Review of three-dimensional ecological modelling related to the North Sea shelf system. Part II: Model validation and data needs, Oceanog. Mar. Biol., 44, 1-60, 2006.

Raick, C., Delhez, E. J. M., Soetaert, K., and Grégoire, M.: Study of the seasonal cycle of the biogeochemical processes in the Ligurian Sea using a 1D interdisciplinary model, J. Marine Syst., 55, 177-203, 2005.

Raick, C., Soetaert, K., and Grégoire, M.: Model complexity and performance: How far can we simplify?, Prog. Oceanogr., 70, 27-57, 2006.

Ressler, P. H. and Jochens, A. E.: Hydrographic and acoustic evidence for enhanced plankton stocks in a small cyclone in the northeastern Gulf of Mexico, Cont. Shelf. Res., 23, 41-61, 2003.

Riegman, R., Stolte, W., Noordeloos, A. A. M., and Slezak, D.: Nutrient uptake and alkaline phosphatase (ec 3:1:3:1) activity of emiliania huxleyi (Prymnesiophyceae) during growth under $\mathrm{n}$ and $\mathrm{p}$ limitation in continuous cultures, J. Phycol., 36, 87-96, 2000 .
Sañudo-Wilhelmy, S. A., Tovar-Sanchez, A., Fu, F. X., Capone, D. G., Carpenter, E. J., and Hutchins, D. A.: The impact of surfaceadsorbed phosphorus on phytoplankton Redfield stoichiometry, Nature, 432, 897-901, 2004.

Sarthou, G., Timmermans, K. R., Blain, S., and Tréguer, P.: Growth physiology and fate of diatoms in the ocean: a review, J. Sea Res., 53, 25-42, 2005.

Schlacher, T. A., Connolly, R. M., Skillington, A. J., and Gaston, T. F.: Can export of organic matter from estuaries support zooplankton in nearshore, marine plumes?, Aquat. Ecol., 43, 383393, 2009.

Schumacher, J. D., Stabeno, P. J., and Bograd, S. J.: Characteristics of an Eddy Over a Continental Shelf: Shelikof Strait, Alaska, J. Geophys. Res., 98, 8395-8404, 1993.

Sempéré, R., Charrière, B., Van Wambeke, F., and Cauwet, G.: Carbon Inputs of the Rhône River to the Mediterranean Sea: Biogeochemical Implications, Global Biogeochem. Cy., 14, 669-681, 2000.

Simpson, J. H.: Physical processes in the ROFI regime, J. Marine Syst., 12, 3-15, 1997.

Sokal, R. R. and Rohlf, F. J.: Biometry: the principles and practice of statistics in biological research, 3 edn., W. H. Freeman and Co., New York, 1995.

Sondergaard, M. and Theil-Nielsen, J.: Bacterial growth efficiency in lakewater cultures, Aquat. Microb. Ecol., 12, 115-122, 1997.

Sterner, R. W. and Robinson, J. L.: Thresholds for growth in Daphnia magna with high and low phosphorus diets, Limnol. Oceanogr., 39, 1228-1232, 1994.

Tesi, T., Miserocchi, S., Goñi, M. A., and Langone, L.: Source, transport and fate of terrestrial organic carbon on the western Mediterranean Sea, Gulf of Lions, France, Mar. Chem., 105, 101-117, 2007.

Thingstad, T. F.: Simulating the response to phosphate additions in the oligotrophic eastern Mediterranean using an idealized fourmember microbial food web model, Deep-Sea Res. Pt. 2, 52, 3074-3089, 2005.

Thingstad, T. F. and Rassoulzadegan, F.: Nutrient limitations, microbial food webs, and biological C-pumps - suggested interactions in a P-limited Mediterranean, Mar. Ecol.-Prog. Ser., 117, 299-306, 1995.

Thingstad, T. F., Skjoldal, E. F., and Bohne, R. A.: Phosphorus cycling and algal-bacterial competition in Sandsfjord, western Norway, Mar. Ecol.-Prog. Ser., 99, 239-259, 1993.

Thingstad, T. F., Zweifel, U. L., and Rassoulzadegan, F.: P limitation of heterotrophic bacteria and phytoplankton in the northwest Mediterranean, Limnol. Oceanogr., 43, 88-94, 1998.

Timmermans, K. R., Van der Wagt, B., Veldhuis, M. J. W., Maatman, A., and De Baar, H. J. W.: Physiological responses of three species of marine pico-phytoplankton to ammonium, phosphate, iron and light limitation, J. Sea Res., 53, 109-120, 2005.

Turner, J. T. and Tester, P. A.: Zooplankton feeding ecology: nonselective grazing by the copepods Acartia tonsa Dana, Centropages velificatus De Oliveira, and Eucalanus pileatus Giesbrecht in the plume of the Mississippi River, J. Exp. Mar. Biol. Ecol., 126, 21-43, 1989.

Tusseau, M. H., Lancelot, C., Martin, J. M., and Tassin, B.: 1-D coupled physical-biological model of the northwestern Mediterranean Sea, Deep-Sea Res. Pt. 2, 44, 851-880, 1997.

Tyrrell, T. and Taylor, A. H.: A modelling study of Emiliania 
huxleyi in the NE atlantic, J. Marine Syst., 9, 83-112, 1996.

Uitz, J., Claustre, H., Morel, A., and Hooker, S. B.: Vertical distribution of phytoplankton communities in open ocean: An assessment based on surface chlorophyll, J. Geophys. Res., 111, C08005, doi:10.1029/2005JC003207, 2006.

Urabe, J. and Watanabe, Y.: Possibility of $\mathrm{N}$ or $\mathrm{P}$ limitation for planktonic cladocerans: An experimental test, Limnol. Oceanogr., 37, 244-251, 1992.

Van Wambeke, F., Christaki, U., and Gaudy, R.: Carbon fluxes from the microbial food web to mesozooplankton. An approach in the surface layer of a pelagic area (NW Mediterranean Sea), Oceanol. Acta, 19, 57-66, 1996.

Vichi, M., Pinardi, N., and Masina, S.: A generalized model of pelagic biogeochemistry for the global ocean ecosystem. Part I: Theory, J. Marine Syst., 64, 89-109, 2007.

Vidussi, F., Marty, J. C., and Chiavérini, J.: Phytoplankton pigment variations during the transition from spring bloom to oligotrophy in the northwestern Mediterranean sea, Deep-Sea Res. Pt. 1, 47, 423-445, 2000.
Vidussi, F., Claustre, H., Manca, B. B., Luchetta, A., and Marty, J. C.: Phytoplankton pigment distribution in relation to upper thermocline circulation in the eastern Mediterranean Sea during winter, J. Geophys. Res., 106, 19939-19956, 2001.

Yin, K., Song, X., Sun, J., and Wu, M. C. S.: Potential P limitation leads to excess $\mathrm{N}$ in the pearl river estuarine coastal plume, Cont. Shelf. Res., 24, 1895-1907, 2004.

Zapata, M., Rodriguez, F., and Garrido, J. L.: Separation of chlorophylls and carotenoids from marine phytoplankton: a new HPLC method using a reversed phase C8 column and pyridinecontaining mobile phases, Mar. Ecol.-Prog. Ser., 195, 29-45, 2000 . 